dergİabant (AİBÜ İlahiyat Fakültesi Dergisi), Bahar 2020, Cilt:8, Sayı:1, 8:145-169

Geliş Tarihi: 06.04.2020

Kabul Tarihi: 13.05.2020

Araştırma Makalesi

Doi: https://doi.org/10.33931/abuifd.714934

\title{
Örfî İstisnanın (İnşallah) Bazı İbadet ve Akitlerdeki İzdüşümü
}

\section{Murat Polat*}

Öz

Usûl-i fikıh, genel olarak hükümlerin teorik boyutunu, fürû-i fıkıh ise pratik boyutunu ele alır. Fıkıh tarihi boyunca usûl-i fıkıh şemsiyesi altında pek çok kavram fürû-i fıkıhta pratik hale gelmiştir. Bu kavramlardan birisi de örfî istisnadır. Örfî istisna (inşallah) şâri'in müslüman her bireyden hayatının bazı alanlarında kullanmasını istediği dini bir emirdir. Onunla arzu edilen her iş hedefine ulaşmakta, onsuz bașlanan her bir iş ise akîm kalmanın yanında ilâhî emre karşı gelme ve isyan içermektedir. Bu sebeple müslüman bir birey için vazgeçilmez olan örfî istisnanın incelenip güncelleşmesi ve tartışmaya açılması son derece önem arz etmektedir. $\mathrm{Bu}$ araştırmada daha önce herhangi müstakil bir fikhî çalışmaya konu olmamış örfî istisna usûl ve fürû-i fikıh açllarından değerlendirmeye tabi tutulmuş, bazı önemli ve güncel fürû-i fikıh meselelerinde örfî istisnanın önemi vurgulanmak amaçlanmıştır. $\mathrm{Bu}$ amaç etrafında mezhep ve fakihlerin daha çok dikkat çeken görüş ve düşünceleri tipsel metotla sergilenmiş, örfî istisnanın bir müslüman için ne kadar önemli olduğu sonucuna ulaşılmıştır.

Anahtar Kelimeler: Meşîet, Örfî istisna, İnşallah, İbadet, Akit.

\section{The Project of the Customary Exception (God Willing) in Some Worships and Contracts}

\begin{abstract}
Usūl-i fiqh generally deals with the theoretical dimension of the provisions and furūi fiqh deals with the practical dimension. Throughout the history of fiqh, many concepts have practiced under the umbrella of usūl-i fiqh. One of these concepts is the customary exception. Customary exception (God willing) is an ordered ritual, in which the poet asks every Muslim individual to use in some areas of his life. With it, every desired job achieves its goal, and every job that begins without it is inconclusive, as opposed to divine command and rebellion. For this reason, it is an utmost importance that the customary exception, which is essential for a Muslim individual is examined and updated and opened for discussion. In this study, the customary exception, which has not been subject to any independent jurisprudence before, has been evaluated in terms of usūl and fürū-i fiqh, and it is aimed to emphasize the importance of customary exception in some important and current fürū-i fiqh issues. Around this purpose, the views and thoughts of the sects and the jurists were exhibited in a typical way and it was concluded that the importance of the customary exception for a Muslim.
\end{abstract}

Keywords: Volition, Customary Exception, God willing, Worship, Convention.

Dr. Öğr. Üyesi, Amasya Üniversitesi İlahiyat Fakültesi, Temel İslam Bilimleri Bölümü, İslam Hukuku Anabilim Dalı, m.polat05@hotmail.com

ORCID ID 0000-0003-1983-5588 


\section{Giriş}

Kâinatta her șeyin olușumu veya hareketi ilâhî iradeyle gerçekleșir. İlâhî irade dışında herhangi bir şeyin gerçekleșmesi olanaksızdır. Dolayısıyla kâinatta vuku bulan her şey ilâhî iradenin varlığına bir delil teșkil etmektedir. Fıkıh terminolojisinde ilâhî irade aynı zamanda "meşîet-i ilâhî" olarak da anılmaktadır. "Meşiêt" (meşiyyet), aslı "şeyee" (شئ) olan "şâe" (شاء) mâzi ve "yeşâü" (يشاء) muzâri fiilinin mastarıdır. Meşîet, lügatte "icat ve irade etmek, mevcut olan şeyi talep etmek" demektir. İ İrade kavramiyla aynı anlamı taşıyan meşîet, iradeden daha özel anlam barındırması yönünle ayrılır. ${ }^{2}$ Bununla birlikte iradenin meşîetten daha özel bir anlam ifade ettiğini savunan dilciler de vardır. Onlara göre iradenin meydana geliş vakti gecikebildiği gibi gecikmeyebilirken; meşîette gecikme asla söz konusu değildir. Ayrıca irade, bir fiili yapmaya azmetmek ya da amacı tasavvur ettikten sonra terk etmek demektir ki, onun üzerine hayırlı, faydalı, lezzetli vb. şeyler terettüp edebilir. Buna karşın meşîet, bir fiili azmetmeye bașlama anlamına gelmektedir. ${ }^{3}$ Keza meșiet-i ilâhî, Allah'ın ezelî bir sıfatı iken; ilâhî irade, kadîm olan zatında hadîs bir sıfatıdır. Fakat her iki kavram Allah'a izâfe edildiğinde ise tek anlamda birleşir.4

Bir bireyin kendi cüz'î iradesini kullanarak küllî irade doğrultusunda önceden tasarladığı genel bir husustan bir veya birkaçının ayrı tutulması kadar doğal bir düşünce yoktur. $\mathrm{Bu}$ düşünce dil ve fikıh terminolojisinde istisna olarak isimlendirilmiştir. Hal böyle iken "meşîet" ile istisna kavramlarının aynı fıkhî çizgide buluştuğu görülmektedir. Şöyle ki, istisna sadece "illâ" (إل) ve diğer istisna edatlarına münhasır olan bir hal değildir. İstisna, bir kimsenin: "Muhakkak bu işi yapacağım inşallah" dediği örnekte olduğu gibi bazen "meşîet" kavramına "ta Iik" (تعليق) de yapılabilir. ${ }^{6}$ Hatta böyle bir kullanım insanlar arasında daha yaygındır. Böyle davranmakla insan, Allah'ın irade ve kaderî tekvin sıfatlarıyla kendi arasındaki bağlantıyı pekiştirmektedir.7 Hele hele bu konunun daha çok kelam ilmiyle yakından ilişkisi de söz konusu olunca örfî istisnanın önemi katlanmaktadır. 0 halde mevzuyla yakından alakası olan istisnanın tarifi ve kısımlarına burada değinmekte fayda vardır.

İstisna sözlük anlamı itibariyle "dürmek, bükmek, ayırıp uzaklaştırmak" anlamlarına gelen "sny" (نثي) kökünden türemiştir.8 Istılahî anlamı ise lafzın

Ebü'l-Bekā Eyyüb b. Musa el-Kefevî, Külliyyât, thk. Adnan Derviș (Beyrut: Müessesetü'r-Risâle, ts.), 75.

2 Ebû Bekr b. Abdilkadir er-Râzî, "Șeyee", Muhtâru's-sihâh, thk. Yusuf Șeyh Muhammed (Beyrut: Mektebetü'l-Asriyye, 1419/1999), 171.

3 Ebû Hilal Hasan b. Abdullah b. Sehl el-Askerî, Mu'cemü'l-furûk, thk. Şeyh Beytullah Bayat (b.y.: Müessesetü'n-Neşri'l-İ̉slâmî, 1412/1991), 35.

Kefevî, Külliyyât, 75.

Ta'lik: Bir hukukî işlemin hükümlerinin yürürlüğe girmesinin veya yürürlükte olan hükümlerinin sonlandırılmasının gelecekte gerçekleşmesi muhtemel bir olaya bağlanmasına denir. Zekiyyüddîn Şa'bân, İslâm Hukuk İlminin Esasları, çev. İbrahim Kâfi Dönmez (Ankara: Türkiye Diyanet Vakfı Yayınları, 1999), 267.

6 Alâüddin el-Kâsânî, Bedâiu's-sanâi (Beyrut: Daru'l-Kütübi'l-İlmiye, 1406/1986), 3/154.

7 Yâsir b. Hüseyn Berhâmî, el-Furkān beyne ulemâi'r-Rahmân, thk. Abdurrahmân b. Abdilkerîm (b.y.: Dâru'l-Minhâc, 1428/2007), 197.

8 Muhammed b. Muhammed Ebü'l-Feyz Zebîdî, "Sny", Tâcu'l-arûs, thk. Mecmûa mine'l-muhakkıkîn (b.y.: Dâru'l-Hidâye, ts.), 37/ 295; Ebü'l-Hasan Seyfeddin Ali b. Muhammed el-Âmidî, el-ïhkâm fí usûli'l-ahkâm, thk. Abdürrezzâk Afîfî (Beyrut: el-Mektebü'l-İslâmî, ts.), 2/292. 
barındırdığı anlamların bazılarının muhtevasından çıkarılması demektir. ${ }^{9}$ Usûlcü ve fakihler nezdinde genel olarak istisna; lafzî, hükmî ve mânevî olmak üzere üç kısımda mütalaa edilmektedir. İstisna edatı "illâ" (ํㅣㄹ ve diğer edatlarla "ğayr", "sivâ", "hâşâa", "adâ", "halâa" (غير، سوى، حاشا، عدا، خلا) kelamın bazı fertlerini hükmün içerisine dâhil etmeyi menetmeye "lafzî istisna" adı verilmektedir. ${ }^{10}$ Lafzî istisna fıkıh terminolojisinde aynı zamanda hakiki veya vaz'î istisna olarak da adlandırılmaktadır. Cümlede istisna edatı "illâ" (إلإ) veya diğer edatlar bulunursa hakiki veya vaz'î istisnadan ${ }^{11}$ söz edilebilir.

Hükmî istisna, herhangi bir akitte bazı aslî unsurların istisna edilmesine denir. ${ }^{12}$ Bir kira akdinde işlemin sadece mal üzerine yapılıp kullanım hakkının akit boyunca istisna edilmesi bu tür istisnaya örnek olarak serdedilebilir.

İstisna edatı olmaksızın ilgili fert veya fertlerin hükmün dışına çıkarılmasına "mânevî (örfî) istisna"13 adı verilmektedir. Fıkhî kaynaklar gözden geçirildiğinde mânevî istisna kavramının yerine örfî istisnanın daha çok tercih edildiği ${ }^{14}$ belirgin olarak göze çarpmaktadır. Bu sebeple araștırmada örfî istisna kavramı yeğlenmiș ve konular bu kavram üzere tasarlanmıștır. Ayrıca bu istisnaların her birisi usûl ve fürûi fıkıh kaynaklarında fazlaca yekûn teşkil ettiği için bu araştırmada günümüze hitap etmesi yönüyle güncel bir konu olan ve insanlar arasında sıkça kullanılmasıyla teamül haline gelen örfî istisna konusu ve bu bağlamda dikkat çeken bazı önemli fikhî konular ele alınmıștır. Zira örfî istisnanın ibadetler başta olmak üzere haber, yemin, nezir, talâk, vaat, akit vb. konularda çokça kullanıldığı görülmektedir. ${ }^{15}$

Araştırmanın yöntemine gelince, bu araştırmada bir grubun içerisinde bulunan görüşlerin en belirgin olanının kuvvetli çizgilerle belirtilmesi anlamına gelen tipsel yöntem ${ }^{16}$ kullanılmıştır.

\section{1. Örfî İstisna Kavramı}

Örfî istisna konusu tanımı, meşruiyeti, önemi, hükmü, yapıldığı meclis, telâfi süresi, şartları, anlamdaş cümle ve kelimeler ve sonuçları olmak üzere birkaç başlık altında incelemeye tabi tutulabilir.

Sa'dî Ebû Ceyb, el-Kāmûsu'l-fikhî (Suriye: Dâru'l-Fikr, 1413/1993), 52; Ebu'l-Abbas Ahmed b. İdrîs b. Abdirrahmân el-Karâfî, ez-Zehîre fi'l-fikh, thk. Muhammed Hacî (Beyrut: Daru'l-Garb, 1414/1994), 4/21. 40. Bu tanımla aslında Hanefiler istisnaya "çıkarmak" değil "menetmek" anlamı yüklemişlerdir. Geniş bilgi için bk. Teftâzânî, Şerhu't-Telvîh, 2/40; Kâsânî, Bedâiu's-sanâii', 3/ 154.

11 Kâsânî, Bedâiu's-sanâi', 3/153-54.

12 Celâlüdddîn es-Suyûtî, el-Eşbâh ve'n-nezâir (Beyrut: Dâru'l-Kütüb, 1410/1990), 380.

13 Şemseddin Muhammed ed-Düsûkī, Hâşiyetü'd-Düsûkī ala'ş-Şerhi'l-kebîr (b.y.: Dâru'l-Fikr, ts.), 3/ 411.

14 Bk. Kâsânî, Bedâiu's-sanâi', 3/153-54; Sa'dî Ebû Hubeyb, el-Kāmûsu'l-fikhî (Dımașk: Dâru'l-Fikr, 1408/1988), 53; Vizâratü'l-evkāf ve'ş-şüuni'l-islâmiyye, "İstisna", Mevsûatül'-fikhiyye (Kuveyt: Dâru's-selâsil, 1427/2006), 3/189; Kefevî, Külliyyât, 1125.

15 Vizâratü'l-evkāf, "İstisna", 3/187.

16 Tipsel Yöntem: Bir grubun içerisinde bulunan argümanların en belirgin olanını kuvvetli çizgilerle göstermektir. Wilhelm Dilthey, Hermeneutik ve Tin Bilimleri, çev. Doğan Özlem (İstanbul: Notos Kitap, 2012), 78. 


\subsection{Tanımı}

Örfî istisna, bazı fukaha tarafından şöyle tarif edilmiștir: "Söz konusu istisna edatları zikredilmeden 'inșallah' sözüyle cümlenin kurulmasıdır". ${ }^{17}$ Mamafih bir cümle hem inşallah hem de istisna edatlarından herhangi birisi zikredilerek kurulursa örfî istisnanın hakiki veya vaz'î istisna şekline dönüşebileceği söylenebilir. Ancak toplum nazarında -sözü uzatmadan olsa gerek- böyle uzun kelimeli bir istisnanın yerine "Allah dilerse, yardımını esirgemezse, nasip ederse, izin verirse ... bu işi yapacağım", gibi kısa kelimeler kullanılmış ve bu kelimeler de örf ve âdet haline gelmiştir. ${ }^{18} 0$ halde bu tür kelimeler de örfî istisna olarak adlandırılabilir. Çünkü her bir konuşan kişi ibâdât, muâmelât, ikrar ve diğer tasarruflarında yemini kendi örfüyle bütünleştirmekte, din ise bu örfün şeriata uygun olanlarını onaylamakta, sonuçta bu alana mahsus yerleşik bir örf meydana gelmektedir. ${ }^{19}$

Bunun yanında "bu avlu onun, bu avlu içerisindeki ev ise benimdir" sözü de örfî istisna barındırmaktadır. Aslında bu sözle "Avlunun tamamı onundur, ancak bu ev hariç" denilmek suretiyle söz kuvvetlendirilmek ve örfî istisnaya dikkat çekilmek istenmiştir. ${ }^{20}$

Örfî istisna mecazî anlamca da "inşallah" demektir. Çünkü o, şart ve şarta bağlı (meşrut) bir özellik taşır. Bu sebeple şart, istisna olamaz. Şart ile istisna arasındaki ilişkiye gelince şart meşruttan şart olmayan durumları çıkarandır. Sonuç olarak şart bazı durumları, istisna ise bazı şahısları muhtevasından çıkaran anlam taşır. $\mathrm{Bu}$ yönüyle şart, istisna olarak isimlendirilebilir. Bu görüşü Hz. Peygamber'in "Yemin eden ve ardından istisna getiren kimse hiç yemin etmeyen kimse gibidir"21 hadisi desteklemektedir. Hz. Peygamber bu hadisinde aslında şart ile mecazî istisnanın aynı şeyler olduğunu dile getirmek istemiștir. ${ }^{22}$ Ayrıca Hanefî fakih Hafâcî (ö. 1069/1659) de taşıdığı özellikler sebebiyle örfî istisnanın hem lügat hem de kullanım açısından şart anlamına geldiğini ileri sürmüştür. ${ }^{23}$

Örfî istisnayla şartın örtüştüğü bir diğer nokta ise kurulan cümlenin sonundaki hükmü değiştirmeleridir. Zira fıkıh usûlündeki genel bir kaideye göre kelamın başı, sonuna bağlıdır. Kelamın sonunu ise istisna ve şart değiştirebilmektedir. Konuyu bir örnekle somutlaștırmak gerekirse, bir koca eşine: "Sen boşsun, bu eve girersen" veya "Sen boşsun, inşallah" dedikten sonra şart veya istisna gerçekleşmeden kadın vefat ederse her ikisinin de mevcudiyeti olayı gerçekleştirmeye münhasır olması veçhiyle talâk vâki olmaz. Buna karşılık koca, eşine ismini söylemeden: "Sen üç

17 Muhammed Alâuddîn İbn Âbidîn, Reddü'l-Muhtâr ale'd-Dürri'l-Muhtâr, (Beyrut: Dâru'l-Fikr, 1412/1992), 3/374. İhyâi'l-Kütübi'l-Arabî, ts.), "Kefârât", 6 (No. 2104). Söz konusu hadisi İbn Mâce, Ebû Hureyre'den S şeklinde rivayet etmiştir. Kemâlüddin Muhammed İbnü'-Hümâm, Fethü'l-kadîr (b.y.: Dâru'l-Fikr, ts.), 4/ 135. Bazı alimler örfî istisnayı kelamı ta'dil etmesi sebebiyle "ta'dil" istisna olarak da adlandırmaktadırlar. Kâsânî, Bedâiu's-sanâi', 3/154.

23 Şihâbüddin Ahmed b. Muhammed el-Hafâcî, Hâşiyetü'ş-Şihâb alâ tefsîri'l-Beydâvî (Beyrut: Daru Sâdır, ts.), 6/ 89; İbn Âbidîn, Reddü'l-Muhtâr, 3/366. 
defa boşsun" der, akabinde kadın vefat ederse cümlenin hükmünü değiștiren bir şey olmadığı ve kadının da hükmü değiştiren bir etken sayılmadığı için talâk vâki olur. ${ }^{24}$

\subsection{Meşruiyeti ve Önemi}

Örfî istisna, adı bizzat Şâri' tarafından konulmuş tevkîfî́25 bir hüviyet taşımaktadır. Şöyle ki, Kur'an'da "Şüphesiz biz, vaktiyle "bahçe sahipleri"ne belâ verdiğimiz gibi, onlara (Mekkeli inkârcılara) da belâ verdik. Hani o bahçe sahipleri, sabah erkenden (fakirler gelmeden) bahçenin ürünlerini devşirmeye yemin etmişlerdi. (Bunu tasarlarken) istisna da yapmıyorlardı ("İnşallah" demiyorlardı)"26 meâli şerifinde zikri geçen "istisna yapmadılar" sözü, "inşallah demediler" anlamına gelmektedir. ${ }^{27}$

Örfî istisnayla ilgili başka bir âyet ise şöyledir: "Hiçbir şey hakkında sakın "yarın şunu yapacağım" deme! Ancak, "Allah dilerse yapacağım" de. Unuttuğun zaman Rabbini an ve "Umarım Rabbim beni, bundan daha doğru olana ulaştırır" de"28 âyeti örfî istisnanın meşîet-i ilâhîye ta'likinin meşruiyetine delil teşkil etmektedir. Söz konusu âyet Hz. Peygamber'in, kâfirlerin bazı sualler sormaları üzerine hiçbir istisnada bulunmadan onlara: "Bunların cevabını size yarın vereceğim" diye karşılık vermesi sebebiyle nazil olmuştur. Allah Teâlâ on beș günlük fetret-i vahiyden sonra bu âyeti indirerek kendisine bir ikazda bulunmuștur. Bu âyetle Allah, Hz. Peygamber'e herhangi bir işi yarın yapmaya niyetlendiğinde örfî istisnayı da bu işe dâhil etmesi gerektiğini vurgulamaktadır. Böylelikle kişi verdiği haberi gerçekleştireceğini kesin olarak ifade etmemiș olur. Bu bağlamda bir kiși: "Ben bu iși mutlaka yapacağım" der, sonra da ölüm veya herhangi bir engel sebebiyle yapmazsa yalancı olur. Fakat aynı kişi: "Ben bu işi inşallah yapacağım" derse bu durumda haber verdiği şeyi muhakkak gerçekleștireceğine dair söz vermemiş olur. ${ }^{29}$

Örfî istisnanın meşruiyetine dair hadisten bir örnek vermek gerekirse, Hz. Peygamber'in "Her âdemoğlunun kalbi Allah Teâlâ'nın parmaklarından iki parmağı arasındadır. Onu sebat ettirmek istediği zaman sebat ettirir, döndürmek istediği zaman da döndürür"30 hadisindeki "istediği zaman" kaydı örfî istisnanın hadislerdeki mevcudiyetine atıfta bulunmaktadır.

Bu bilgiler ışığında bir kimse eşine: "Sen bir talâkla boşsun inşallah, sen iki talâkla boşsun Allah dilemezse" şeklinde bir cümle kurarsa her iki durumda da talâk meydana gelmez. Birincisinde talâk, örfî istisna amel ettiğinden; ikincisinde ise cümle meşîet-i ilâhînin olmayışına ta'lik edildiğinden gerçekleşmez. Hâlbuki Allah'ın her fiilin gerçekleşmesini dilediği gibi talâk fiilinin de gerçekleşmesini dilemesi herkesçe

24 İbn Âbidîn, Reddü'l-Muhtâr, 3/287.

25 Tevkîfî: İsmi bizzat şâri' tarafından konulan şey demektir. Mahmûd Abdurrahmân Abdülmün'im, Mu'cemü'l-mustalahât (b.y.: Dâru'l-Fazîle, ts.), 1/497.

26 Kur'ân-ı Kerîm Meâli, çev. Halil Altuntaş - Muzaffer Şahin (Ankara: Diyanet İşleri Başkanlığı Yayınları, 2009), el-Kalem 68/17-18.

27 İbnü'l-Hümâm, Fethü'l-kadîr, 4/136-37; İbn Âbidîn, Reddü'l-Muhtâr, 3/366.

28 el-Kehf 18/23-24. Örfî istisnanın varlığına delalet eden başka âyetler için bk. el-Mâide 5/48; Hûd 11/33, 107; el-A'râf 7/89; Yusuf 12/99; el-Kehf 18/69; Âli İmrân 3/6, 26; el-En'âm 6/125.

Ebû Abdillah Muhammed b. Ahmed el-Kurtubî, el-Câmi' li Ahkâmi'l-Kur'ân, thk. Ahmed Berdûnî (Kahire: Dâru'l-Kütübi'l-Mısriyye, 1383/1964), 10/ 385; Ebû Abdillah Fahrüddîn Muhammed b. Ömer er-Râzî, et-Tefsîru'l-kebîr (Beyrut: Dâru İhyâi't-Turâs, 1420/1999), 21/ 450. 
bilinen bir gerçektir. Fakat koca, meşîet-i ilâhî olmaksızın boşama fiilini gerçekleștirmek istemiştir. $\mathrm{Bu}$ ise olayın vukuunu iptal etmekte ${ }^{31}$ ve söz nükte olmaktan öteye gitmemektedir.32 Buradan hareketle örfî istisnanın kurulan her bir yargı cümlesi için zaruri olduğu söylenebilir. Çünkü meşîet-i ilâhînin "Bir şeyi dilediği zaman, O'nun emri o șeye ancak "Ol!" demektir. 0 da hemen oluverir"33 âyeti kerimesi çerçevesinde düşünüldüğünde gerçekleşmesi kesinlik arz eden bir olgudur. 0 halde insana gerçekleșmesini istediği her bir olayın zımnında inşallah sözünü söylemesi, söylememesi durumunda ise o olayın gerçekleşmeyeceğini kesin olarak bilmesi düșer. ${ }^{34}$ Zaten müminlerin nazarında herhangi bir işin evvelinde meşîet-i ilâhînin çokça zikredilmesinden dolayı "ism-i mevsûl" 35 olduğu ve zamanla örf haline geldiği bir gerçektir. ${ }^{36} \mathrm{Bu}$ şekilde davranan müminler Allah'ın iradesinin kendi iradelerinden daha üstün ve galip olduğunu kabullenmekte ve yalancı pozisyonuna düşmekten kurtulmaktadırlar. ${ }^{37}$

İslâm şeriatında istisna, aslında ümmetin yararı gözetilerek konulmuş bir çözüm yoludur. Zira şeriatta bir şeyi veya birisini alternatif bir çözüm için kullanmamak veya başkasının selameti için akdedilen sözü bozmamak asıl iken, şeriat istisnayı, yapılan bağlayıcı yemin için bir çıkış kapısı tayin etmiştir. Şu kadar var ki, çıkış kapısı olmayan nezir kefâretinin yemin kefâretiyle çözüme kavuşturulması, nezrin yeminle eşitlendiği izlenimi oluşturmaktadır. ${ }^{38}$ Kaldı ki örfî istisnanın akdedilen bir yemin için çıkış yolu veya kefâret olabileceği konularının bazı fukaha arasında tartışılması ${ }^{39}$ bu düşünceyi ispatlar mahiyettedir. Nitekim kefâret, bozulan yeminin bizzat kendisini değil günahını kaldırma; örfî istisna ise yeminin bozulmasını engelleme niteliğiyle dikkatleri çekmektedir. Bu sebeple bir cümlede sonuca tesir ettikleri için hem istisna hem de kefâret yan yana gelmemektedir. ${ }^{40}$

Daha önce belirlemiş olduğu herhangi bir şeyi başkasına vermeyi vaat edip bunu gerçekleștireceğine dair yemin ettiği halde bu vaadini yerine getirmeyen kişiden, Allah Teâlâ sadece yemin kefâreti talep etmektedir. Bunun ardından da "Hiçbir şey hakkında sakın "yarın şunu yapacağım" deme! Ancak, "Allah dilerse yapacağım" de. Unuttuğun zaman Rabbini an ve "Umarım Rabbim beni, bundan daha doğru olana ulaștırır" de" 41 buyurarak doğru olan yolun bu şekilde olduğunu göstermekte, örfî istisnayı insanlığın istifadesine sunmaktadır. Bazı ulemâ nazarında istisnanın yemin mesabesinde olduğu ve kefâretinin yemininkiyle aynı kabul edildiği ${ }^{42}$ de hesaba katılırsa bu düşüncenin haklılığı tezahür etmektedir. Bu minvalde

31 İbn Âbidîn, Reddü'l-Muhtâr, 3/370-71; Ebû Abdillah Muhammed b. Ebû Bekr b. Kayyim elCevziyye, I'lâmü'l-muvakkîn (Suudi Arabistan: Dâru İbni'l-Cevziyye, 1423/2002), 5/472.

Teftâzânî, Şerhu't-Telvîh, 1/227; İbnü'l-Hümâm, Fethü'l-kadîr, 4/137.

Yâsîn 36/82.

Ali b. Ahmed b. Said b. Hazm, el-íhkâm fî usûli'l-ahkâm, thk. Ahmed Şakir (Beyrut: Dâru'l-Âfâk, ts.), 5/ 19; Teftâzânî, Șerhu't-Telvîh, 1/227.

İsm-i Mevsûl: Anlamı ancak sıla cümlesi diye isimlendirilen bir cümle veya şibih cümleyle tamam olan isimdir. Münazzametü'l-arabiyye, “Vsl”, Mu'cemü'l-arabiyyi'l-esâsî (b.y.: Durûs, 1419/1999), 1313.

İbnü'l-Hümâm, Fethü'l-kadîr, 4/136, 140.

Râzî, et-Tefsîru'l-kebîr, 21/450.

Karâfî, ez-Zehîre, 4/23.

Karâfî, ez-Zehîre, 4/24.

Âmidî, el-İhkâm, thk. Abdürrezzâk Afîfî, 2/291; İbn Kayyim el-Cevziyye, Ílâmü'l-muvakklîn, 5/ 474.

41 el-Kehf 18/23-24

42 Ebû Saîd Abdüsselâm Sahnûn, el-Müdevvene, (Beyrut: Dâru'l-kütüb, 1414/1994), 1/584. 
herhangi bir șekilde başkasına vaatte bulunan ve "inşallah" demeyen Allah'a isyan etmiș ve onun emrine muhalefette bulunmuștur. Allah'a mâsiyet içeren her fiil ise reddedilir ve geçersiz kabul edilir. Ayrıca Allah Teâlâ vâcip olan borçlar, yerine getirilmesi gereken emanetler ve kișilerin karşılıklı sahip olduğu haklar hakkında âsi olanları uyarmakta, mâni olanları kınamakta ve bu fiillerin mutlaka yerine getirilmesini istemektedir. Bu konudaki en açık delil ise "Doğru yolu göstermek Allah'a aittir. Yolun eğrisi de vardır. Allah dileseydi, hepinizi doğru yola iletirdi"43 âyetidir. ${ }^{44}$

\subsection{Hükmü, Yapıldığı Meclis ve Telâfisi}

İnsanoğlunun mümkün olsun veya olmasın fitratına bir dileği, bir arzuyu, bir isteği gerçekleştirme temennisi yerleştirildiği bilinen bir hakikattir. Bu duygu günlük hayatta çoğu zaman "bâri", "keșke", "tek", "ne olurdu", "ne olaydı", "ne olsaydı" gibi kelimelerle dile dökülmektedir. Kur'an'da bu temenniler çoğu zaman "lev" (لو (لو edatıyla ifade edilmiştir. ${ }^{45}$ Çünkü bir şeyin, kendi haricindeki bir şey sebebiyle imkânsızlığ ${ }^{46}$ söz konusu olunca çoğu zaman "lev" edatı kullanılmaktadır. Söz konusu edatın bir müminin hayatında iş işten geçtikten sonra kullanılması, Hz. Peygamber'in "... Senin başına bir iş geldiğinde 'ben olsam şunu şunu yaparım' deme. 'Allah'ın takdiri böyleymiş; O dilediğini yaptı' de. Zira 'Keşke şöyle yapsaydım' sözü, şeytanın vesvesesine yol açar" 47 hadisine binaen şeytanın işine davetiye çıkarmaktır. $O$ halde bu duruma düşmemek için meşîet-i ilâhîye razı olmak ve örfî istisnayı dilden düşürmemek zorunlu bir görevdir. ${ }^{48}$

İnsanoğlunun istikbale yönelik birtakım vaat ve istekleri de olabilir. Bu vaat ve isteklerin Allah'ın dilemesiyle gerçekleşmesi, örfî istisnanın istenen cümleye ta'lik edilmesine bağlıdır. Aksi halde tüm istekler boşa çıkabilmekte ve hayalden öteye gidememektedir. Nitekim Hz. Peygamber'in şu hadisi bu gerçeği desteklemektedir: Hz. Süleyman bir meleğe: "Ben bu gece yüz kadınla muhakkak beraber olacağım, onlar da Allah yolunda savaşan yüz çocuk doğuracak" deyince melek de kendisine: "İnşallah $d e$ " buyurdu. Hz. Süleyman "inşallah" demedi ve demeyi de unuttu. İstediği fiili yapınca sonuçta sadece bir kadın yarım bir çocuk dünyaya getirdi. Bunun üzerine $\mathrm{Hz}$. Peygamber: "Şayet 0 , inșallah deseydi yeminini bozmamış ve emeline ulaşmış olurdu" buyurdu. ${ }^{49} \mathrm{O}$ halde istikbale dair bir isteğin boşa çıkmaması için örfî istisnanın zikredilmesi zaruridir. Ayrıca söz konusu hadisten örfî istisnayı söylemeyi unutan kişiye de makamı ve görevi ne olursa olsun hatırlatılması gerektiği sonucu da çlkarılabilir. Zira Hz. Peygamber'in "Ben de sizin gibi bir beşerim. Sizin gibi ben de unutabilirim. Unuttuğum zaman bana hatırlatın" 50 hadisi bu konudaki ciddiyeti gözler önüne sermesi bakımından çok mühimdir. Hal böyle olunca bir başkasına vaatte bulunan bir kimsenin "inşallah" diyerek vaadini meşîet-i ilâhîye bağlamasının fikhî

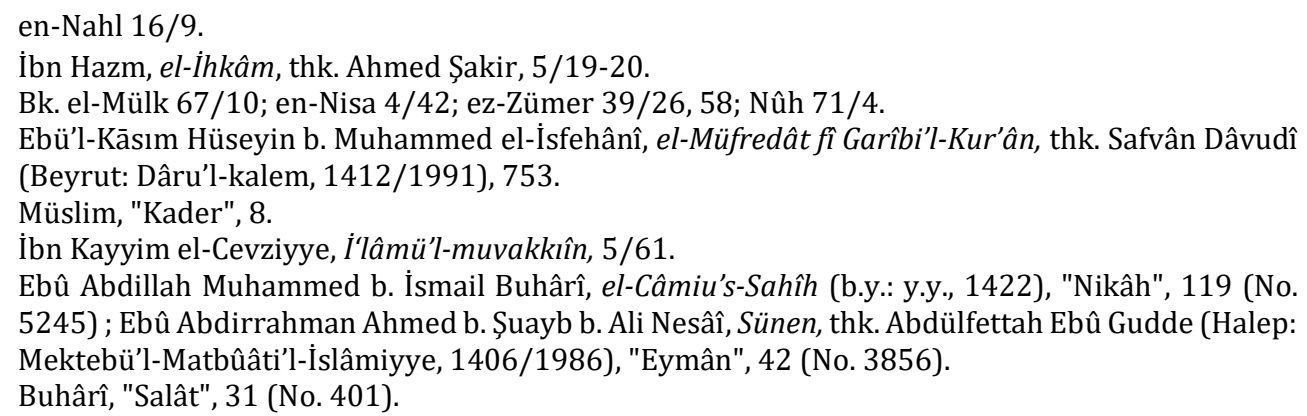


hükmü, Fahreddîn er-Râzî’ye (ö. 606/1210) göre vâcip,51 İmam Gazzâli'ye (ö. 505/1111) göre ise evlâdır. Buna karșın vaadini meșiet-i ilâhîye bağlamayan kimse ise Cessâs'a (ö. 370/981) göre kötü (mekruh) bir iş yapmış, Hanbelîlere göre yasağı (haram) çiğnemiştir. ${ }^{52}$

Başka bir görüşe göre, "Hiçbir şey hakkında sakın "yarın şunu yapacağım" deme! Ancak, "Allah dilerse yapacağım" de. Unuttuğun zaman Rabbini an ve "Umarım Rabbim beni, bundan daha doğru olana ulaştırır" de"53 âyetinin yemin ahkâmıyla ilgisi yoktur. Devamında gelen âyette "Unuttuğun zaman Rabbini an"54 buyurulması örfî istisnanın mendub oluşuna delalet etmektedir. Dolayısıyla bir işte örfî istisna yapmak unutulursa hatırlandığında derhal istisna yapılarak bu durumun telâfi edilmesine bu âyet işaret etmektedir. ${ }^{55}$ Hatta söz konusu âyetin sebeb-i nüzûlünün örfî istisnanın telâfisinin emredilmesi yönünde farklı bir yoruma da burada değinmekte yarar vardır. Şöyle ki, Hz. Peygamber kâfirlere ruh, mağaradaki gençler ve Zülkarneyn'le ilgili bilgi sözü verince ilgili âyet nazil oldu. Ancak Hz. Peygamber bu âyetin gereğini unutmuş, bir yıl sonra hatırlamış, akabinde örfî istisnanın telâfisini emreden "Unuttuğun zaman Rabbini an"56 âyeti nazil olmuştur. Burada Hz. Peygamber'in unutması, onun bu emri nefsinde gizlediği, kalbinde irade ettiği, yapmaya azmettiği ve sonunda diliyle örfî istisnayı söylediği şeklinde yorumlanabilir. ${ }^{57}$

Örfî istisnanın alenen zikredilmesi naslarda istenen bir davranış olduğuna göre gizlice söylenmesi veya hiç söylenmemesi yerine, söylenmiş kabul edilip kişinin zimmetine bir borç olarak yazılmasında herhangi bir dinî beis bulunup/bulunmadığı sorusuna İbn Abbas (ö. 67/687) şöyle cevap vermiştir: Hz. Peygamber'in, kâfirlerin ruh, mağaradaki gençler ve Zülkarneyn hakkında bilgi talep etmeleri üzerine örfî istisnayı zikretme hususunda sükût buyurması, istisnayı gizlemenin doğru olacağı inancını taşımasından kaynaklanabilir. Zaten istisnayı gerekli yerlerde zikretmeyen bir kimse, kendisi ile Allah arasında istisnayı zikretme borcunu peşinen yüklenmiş demektir. ${ }^{58}$ Bu meyanda bir kişinin, örfî istisnayı zikretmediğinde onu ilgili cümleye en kısa zamanda ta'lik etme borcunun zimmetine yazıldığı açıkça söylenebilir.

Diğer taraftan fazla uzatmamak şartıyla istisnayı aynı mecliste olup munfasıl olarak zikretmek de câizdir. Bazı ashap Hz. Peygamber'in: "Allah'a yemin olsun ki Kureyş ile savaşacağım" 59 sözünden sonra bir süre sükût etmesini, akabinde "İnşallah" buyurmasını delil göstererek istisna ile kelam arasında uzun süre olmamak kaydıyla fâsıla yapılabileceğini savunurlar. Onun bu şekilde davranmasının sırrı, "Unuttuğun zaman rabbini an"60 âyeti gereği yemine olan saygısındandır. ${ }^{61}$

Telâfi süresine gelince, örfî istisnada cumhur ulemâya göre hemen, yani söylenen sözün peşinden muttasıl olma; İmam Evzâî (ö. 157/774) ve Hasan Basrî'ye

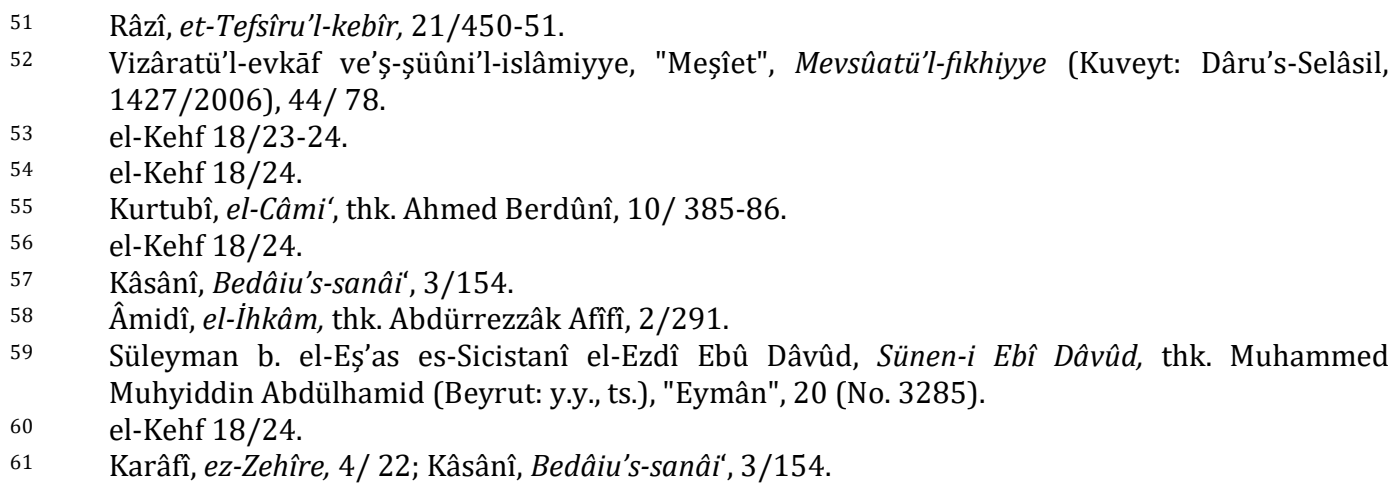


(ö. 110/728) göre akdin yapıldığı meclis; Atâ b. Ebî Rebah'a (ö. 114/732) göre sütü bol olan bir devenin sağılabileceği zaman dilimi; Saîd b. Cübeyr'e (ö. 94/713) göre dört ay; İbn Abbas'a göre bir yıl, bașka bir kavle göre ise iki yıl esas alınır. ${ }^{62} \mathrm{Bu}$ görüşlerden akıl ve mantığa en uygun olanı örfî istisnanın cümleye muttasıl olmasıdır. Çünkü kişi, söyleyeceğini sarf etmeden önce mutlaka iyice düşünmeli, ağzından çıkanın yaydan çıkan ok gibi geri dönmeyeceğini bilmeli ve ona göre hareket etmelidir. İslâm ümmeti arasında örfî istisnanın kurulan cümlenin peşinden söylenmesi hususunda bir örfün oluşması ${ }^{63}$ da bu görüşü destekler mahiyettedir. Aslında böyle bir örfün oluşmasına zemin hazırlayan "Yine bunun gibi, Allah'a ortak koşanların çoğuna, koştukları ortaklar, çocuklarını öldürmelerini güzel gösterdi ki; onları helâke sürüklesinler ve dinlerini karıștırıp onları yanıltsınlar. Eğer Rabbin dileseydi, bunu yapamazlardı. Artık sen onları uydurdukları ile baş başa bırak"64 mealindeki âyet ve insanlardaki niyet ettiği fiilin bir an önce gerçekleşme ümidi olduğu ileri sürülebilir.

\section{4. Şartları}

Örfî istisnanın geçerli olabilmesi için birkaç şartın bulunması elzemdir. Cumhura göre diğer istisna çeşitlerinde olduğu gibi örfî istisnada da kastın bulunması şarttır. Herhangi bir konuda yemin eden kimsenin istisnasının geçerliliği istisna manasını kastetmesine bağlıdır. 0 halde sözün gelişi ya da herhangi bir kasıt olmadan bozulan yeminde istisna bağlayıcı değildir. Hanefî mezhebinde ise "illâ" ( $(ا ٕ l)$ ve diğer istisna edatlarıyla kurulan cümlelerde kasıt şart olmadığı gibi örfî istisnada da kasıt şart değildir. Bu minvalde Hanefîlere göre bir kişi eşini anlamını bilmediği inşallah içeren bir istisna cümlesiyle boşamaya kalksa talâk geçersiz olur. Mezhep içi bir görüşe göre ise bu konuda niyete de ihtiyaç duyulmuştur. ${ }^{65}$ Başka bir görüşe göre şer'î sebepler müsebbiplerinin fiile dönüşmesine bağlıdır. Bu nedenle bir fiile kastetmek onu yapmak değildir. Namazı kılmaya yönelmek namaz kılmak olmadığı gibi, hırsızlığa yönelmek de hırsızlık yapmak anlamına gelmemekte, sırf kasıt sebebiyle de hırsızın elinin kesilmesi gerekmemektedir. Sonuç olarak, hüküm ancak sebebin fiiliyata dönüşmesiyle terettüp ettiği için niyet, yeminin bozulmasında örfî istisnanın yerine geçmez. Bilakis yeminin kalkması, şartları üzere konuşulmaya bağlıdır. ${ }^{66}$

Aynı düşünceye sahip bazı Mâliki fakihler, çözüm için konulan örfî istisnayı telaffuz etmenin yeterli olduğunu, şer'î sebeplere kastetmenin niyetin yerine geçmeyeceğini, niyetin kelamın bulunmadığı tahsis ve takyitte bir sebep olabileceğini ve dolayısıyla niyetin bu ikisinde müstakil olarak zikredilmesinde bir beis

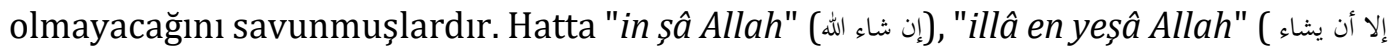
لال ve buna benzer şekilde kurulan istisna cümlelerinde dilin hareket etmesinin yeterli olabileceğini dahi dile getirmişlerdir. ${ }^{67}$ Hanefîlerden bazı fakihler de bu görüşü benimsemiş, buna ilave olarak ses duyulmasa bile örfî istisnanın harflerinin

\footnotetext{
62 Kurtubî, el-Câmi', thk. Ahmed Berdûnî, 10/ 385-86; Râzî, et-Tefsîru'l-kebîr, 21/451; İbnü'lHümâm, Fethü'l-kadîr, 4/139.

63 İbnü'l-Hümâm, Fethü'l-kadîr, 4/140.

64 el-En'âm 6/137.

65 İbn Âbidîn, Reddü'l-Muhtâr, 3/368.

66 Karâfî, el-Furûk, 3/72, 93.

67 Karâfî, ez-Zehîre, 4/23.
} 
söylemesinin kâfi olacağını ileri sürmüşlerdir. ${ }^{88}$ Ayrıca örfî istisnayı söyleyen kişinin işitmesi de şart değildir. Bu minvalde sağır bir kimse işitmese bile istisnası sahihtir. ${ }^{69}$

Örfî istisnanın bağlayıcı olabilmesi, sözün gelişigüzel veya sehven ifade edilmesine değil, doğrudan veya kararlı telaffuzuna bağlıdır. Aksi halde sarf edilen istisnanın hiçbir yararı yoktur. ${ }^{70}$ Dolayısıyla bir kimse: "Ben bu eve girmeyeceğim" derse ardında da kalbinden "inşallah" diyerek istisna yapsa böyle bir istisnanın kişiye ne bir fayda sağlaması mümkündür ne de fıkhî bir hükmü doğurur. Aynı hüküm zikri geçen istisnadan sonra boşadığına dair bir delil/beyyine getirilmeyen talâk için de söz konusudur. ${ }^{71}$

Hakiki istisnanın amel edebilmesi için kelama muttasıl olması ve araya öksürük veya aksırık gibi irtibatı koparan herhangi bir fâsılanın dahi girmemesi önemlidir. ${ }^{72}$ Buna karşılık örfî istisnanın, bir cümle kurmasa bile kelama bitişik olması yeterli görülmüştür. Dolayısıyla örfî istisna yapan kimse istisnasını öksürük, aksırık veya esnemeyle fâsıla yaparak ifa etse istenen amaca herhangi bir halel getirmez. ${ }^{73}$ Ancak Ebû Yusuf'a (ö. 182/798) göre kelam zikredildikten sonra örfî istisnanın bașına atıf edatı "vav" (الو او العاطفة) veya "fâ" (الفاء العاطفة) gelirse kelam ile istisna arasına fâsıla girdiği için istisna amel etmez. Bu görüşü bir örnekle vuzuha kavuşturmak gerekirse, bir kimse eşine: "Sen boşsun ve inşallah" veya "Sen boşsun, feinşallah" derse söz konusu harfler bir dolgu veya sekte mesabesinde kabul edildiği ve ta'like mâni olduğu için istisna amel etmemekte, talâk vâki olmaktadır. Ancak örfî istisna zikredildikten sonra kelam ifade edilir ve başına yukarıdaki harfler gelirse istisna sahih olur. ${ }^{74}$

Örfî istisnanın amel edebilmesi için başka bir şart ise istisna ile kefâretin aynı cümlede bulunmamasıdır. Zira kefâret, bozulan yeminin bizzat kendisini değil, günahını kaldırma; örfî istisna ise yeminin bozulmasını engelleme niteliği taşıdığı ${ }^{75}$ için bir cümlede hem istisna hem de kefâretin yan yana gelmemesi mühimdir. ${ }^{76}$

Örfî istisna aynı zamanda atıf edatı "vav"la da kullanılmamalıdır. Çünkü Arap Edebiyatı'nda atıf harfi olan "vav", çoğu dilciye göre "birliktelik" anlamında kullanılır. Bir kimse Allah'ın dışındaki varlıkları da örfî istisnaya dâhil etmek istediğinde "vav" harfi yerine "sümme" (F) edatını kullanması naslar açısından yerinde bir davranış olacaktır. Nitekim Hz. Peygamber'in "Sizler Allah ve falanca kişi dilerse demeyin. Bunun yerine Allah dilerse sonra da falanca kişi dilerse deyin"77 hadisi bu konuya atıfta bulunmaktadır. Söz konusu hadis, "vav" edatının tertip anlamında olmadığını, birliktelik anlamına geldiğini vurgulamaktadır. Şayet "vav" edatı tertip anlamında kullanılmış olsaydı bir başka tertip edatı olan "sümme" edatının da aynı hadiste kullanılmaması gerekirdi. Ayrıca tertip amaçlı "vav" edatıyla kurulan cümlelerde atıf

68 Kâsânî, Bedâiu's-sanâi', 3/154; Ebû Bekr Alâuddin es-Semerkandî, Tuhfetü'l-fukahâ (Beyrut: Dâru'l-Kütüb, 1414/1994), 2/ 193. Aksi bir görüş için bk. Kâsânî, Bedâiu's-sanâi', 3/155.

Kâsânî, Bedâiu's-sanâi', 3/155.

Vizâratü'l-evkāf, "İstisna", 3/194.

Kurtubî, el-Câmi', thk. Ahmed Berdûnî, 6/274.

Meselâ bir kimse: "Bütün insanları gördüm" dedikten bir ay ya da bir yıl sonra: "Zeyd hariç" derse sarf ettiği cümlenin hiçbir anlamı yoktur. Ebü'l-Meâlî Rüknüddin b. Yusuf el-Cüveynî, et-Telhîs fí usûli'l-fikh, thk. Abdullah Nebâlî (Beyrut: Dâru'l-Beşâir, ts.), 2/ 64-65. 39; Semerkandî, Tuhfetü'l-fukahâ, 2/193.

74 Kâsânî, Bedâiu's-sanâi', 3/ 158-59; Semerkandî, Tuhfetü'l-fukahâ, 2/194.

75 Âmidî, el-İhkâm, thk. Abdürrezzâk Afîfî, 2/291.

76 İbn Âbidîn, Reddü'l-Muhtâr, 3/704.

77 Ebû Dâvûd, "Edeb", 84 (No. 4980). 
ile matuf ilişkisi çerçevesinde takdim ve tehir mümkün değilken, pek çok âyette de ifade edildiği gibi ${ }^{78}$ birliktelik amaçlı " $v a v$ " edatında takdim ve tehir olağandır. ${ }^{79} \mathrm{Bu}$ mevzunun en dikkat çekici tarafını İbn Kayyim el-Cevziyye (751/1350) dile getirmiștir. O'na göre bir kiși, lafzen de olsa örfî istisnada Allah ile bașka birisini atıf edatı " $v a v$ " harfiyle kullandığında şirke düşebilir. Bu sebeple bir istidlal metodu sayılan sedd-i zerâi' (kötülüğe giden yolların tıkanması) çerçevesinde kastî veya fiilî olarak şirke düşmenin önüne geçmek için bu tür istisnadan sakınılması gerekir. Nitekim Hz. Peygamber'in "Her kim Allah'a ve resulüne itaat ederse doğru yolu bulmuştur, o ikisine isyan ederse sapmıştır" diyen bir hatibe: "kalk ve git, kötü hatip"80 buyurarak onu zemmetmesi; "Allah dilerse ve sen dilersen" diyen bir kişiye de: "Yazıklar olsun! Beni Allah'a ortak mı kıldın" 81 buyurması, şirkin kökünü lafızlarda da olsa sökmeye yönelik sedd-i zerâi' kapsamında düşünülen girişimlerdir.82 Örfî istisnanın sadece Allah'a ya da sadece onun dışındaki varlıklara ta'lik edilmesi de bu bağlama dâhil edilebilir. Çünkü bir kelamda örfî istisnanın hem Allah'a hem de onun dışındaki varlıklara ta'liki, ikisinden birinin varlığı bilinmeyen iki şarta ta'lik edilmesi demektir. İki şarta bağlanan şey ise hüküm ifade etmemektedir. Meselâ bir kimse eşine: "Sen boşsun Allah dilerse ve Zeyd dilerse" derse kelam iki şarta ta'lik edildiği için talâk yok hükmündedir. ${ }^{83}$

Meşîet ve irade kavramları Allah'a izâfe edildiğinde herhangi bir anlam ve görev farklılı̆̆ bulunmamaktadır. Nitekim "Allah dilediğini yapar"84 âyeti, meşîeti, "Şüphesiz Allah istediği hükmü verir"85 âyeti ise iradeyi vurgulamaktadır.86 Buna karşılık örfî istisna bir insanın meşîetine ta'lik edildiğinde amel edebilmesi için sadece dileme anlamı taşıyan "şâe" (شاء), "yeşâu" (يشاء) ve müştakkı olan sîgalarla kullanılması da örfî istisnanın amel etme şartlarından addedilebilir. Zira bu sîgalar dışında kurulan örfî istisna amacına ulaştırıcı bir rol üstlenmeyebilir. Konuyu bir örnekle somutlaştırmak gerekirse, boşamaya niyetli bir koca, eşine: "Seni boşamayı diledim" dediğinde meşîet, var olan şeyi haber verdiği için boşama vâki iken; koca, eşine: "Seni

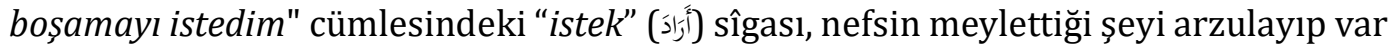
olan şeyi haber vermediğinden boşama vâki olmaz. ${ }^{87}$ Yine meşîet, fiilin o anda mevcut olan şeye tahsisi iken; irade, fiilin o anda mevcut olmayan şeye de tahsisi demek olduğundan bir koca, eşine: "Talâkını dile" der, eşi de dilerse talâk meydana gelirken; "Talâkını irade et" der, eși de irade ederse talâk meydana gelmez.88

\footnotetext{
$78 \quad$ Bk. el-A'râf 7/179; el-Enbiya 21/72, 78.

79 Ahmed b. Ali Ebû Bekr er-Râzî el-Cessâs, el-Fusûl fi'l-usûl (Kuveyt: Vizâratü'l-evkāf, 1414/1994), 1/ 86-87; Ebû Abdillah Bedruddin b. Bahadır ez-Zerkeşî, el-Bahru'l-muhît (Beyrut: Dâru'l-Kütüb, 1414/1994), $3 / 143$.

80 Ebû Dâvûd, "Salat", 228 (No. 1099).

81 Ebû Abdirrahman Ahmed b. Șuayb b. Ali en-Nesâî, es-Sünenü'l-kübrâ, thk. Hasan Çelebi (Beyrut: Müessesetü'r-Risâle, 1421/2001), 9/ 362.

82 İbn Kayyim el-Cevziyye, I'lâmül'-muvakklîn, 5/30-32.

83 Kâsânî, Bedâiu's-sanâi', 3/ 160.

84 Âl-i İmrân 3/40.

85 el-Maide $5 / 1$

86 Kefevî, Külliyyât, 75.

87 İbnü'l-Hümâm, Fethü'l-kadîr, 4/ 104. Bu hüküm sadece boşayanın kendisi için vâkidir. Boşayan, kadın veya üçüncü şahıs olursa farklı hükümler barındırmaktadır. Bk. İbnü'l-Hümâm, Fethü'lkadîr, 4/ 136. 


\subsection{Anlamdaş Cümle ve Kelimeler}

Örfî istisna anlamına gelen pek çok cümle ve kelime mevcuttur. Bunların başında "mâşallah" (ما شاء الله) gelmektedir. Zikredildiği cümlede kelamı iptal etme yönüyle "mâşallah" ile "inşallah" arasında herhangi bir anlam veya görev farklılığı bulunmamaktadır. ${ }^{99}$ "İnşallah" sözü kullanılmadığında çoğu kez "mâşallah" sözünün kullanılması bu tezi desteklemektedir. "İnşallah" kelimesiyle aynı anlamda kullanılsa da "mâşallah" kelimesi bazı yönleriyle ondan ayrılmaktadır. Sehl bin Huneyf'e yıkanırken nazar atmasıyla onu hasta eden Amr bin Rebîa'ya Hz. Peygamber'in: "Sizden biriniz neden din kardeşini öldürüyor? Biriniz kardeşinde beğendiği, hoşuna gittiği bir şey gördüğü zaman ona mübarek olması için dua etsin"90 buyurmasına binaen İslâm toplumunda "mâşallah" kelimesi, bir kimsenin başka birisine nazar değmesini engellemek için sarf edilir.

Bu kavram aynı zamanda Hz. Peygamber hayatta iken Kur'an'da neshin varlığının câiz olduğunu ifade için de kullanılmıştır. Şöyle ki, "Sana Kur'an'ı okutacağız ve sen onu unutmayacaksın. Ancak Allah'ın dilediği başka. Şüphesiz 0, açık olanı da bilir, gizliyi de"91 buyurularak Kur'an'da neshin câiz olduğu "mâşallah" kelimesiyle ifade edilmektedir. ${ }^{92}$ Konuyla bağlantısı olması hasebiyle nesh ile bu tür istisnanın farkını da burada belirtmek yerinde olacaktır. Nesh, lafzın muhtevasına giren her şeyin hükmünü tamamen kaldırma; örfî istisna ise kelama sonradan dâhil olup lafzın hükmünü menetme anlamı taşımaktadır.93

"Inșallah" terimi bazen de kendisiyle aynı anlamı barındıran ve "Ancak Allah dilerse" ş̧eklinde tercüme edilen "illâ en yeşâ Allah" (إلا أن يشاء الله (şeklinde ifade edilmiştir. Bu cümle aynı zamanda Arap dilinde "istînâf" anlamı da taşımaktadır. İstinaf, sözlük anlamı itibariyle "Başlangıç, yeniden başlama" gibi anlama gelmektedir.94 Meânî ilminde istînâf, arada "vav" bağlacı bulunmadan evvelki cümlenin gerektirdiği ve bu cümlede gizli bulunan soruya cevap sadedinde olması nedeniyle sonraki cümleyi ayırmaya denir. Kısaca, evvelki cümleye arada "vav" edatı olmaksızın ayırmaya istînâf adı verilir.95 Meselâ "Hem sizin O'na ortak koştuklarınızdan ben korkmam; ancak Rabbimin bir şey dilemiş olması başka" 96 âyeti ve "Allah dilemedikçe ben kendime bir zarar verme ve bir fayda sağlama gücüne sahip değilim"97 âyetinde zikri geçen istisna, istînâf anlamını çağrıştırmaktadır.98

Mâce, "Tıb", 32 (No. 3509). Söz konusu hadiste geçen "Ona mübarek olması için dua etsin" buyruğu Mâşallah, Bârakallah şeklindeki şerh edilmiştir. Muhammed b. Ahmed b. Hamza Şihâbüddîn Remlî, Şerhu Sünen-i Ebî Dâvûd, thk. Hâlid Rıbâd (Mısır: Dâru'l-Felâh, 1437/2016), $15 / 600$.

el-A'lâ 87/6-7.

Ebû Bekr Şemsü'l-eimme Muhammed es-Serahsî, Usûlü's-Serahsî (Beyrut: Dâru'l-Marife, ts.), 2/ 78.

Ebû Hâmid Muhammed b. Muhammed el-Gazzâlî, el-Mustasfâ, thk. Muhammed Abdüsselâm (Beyrut: Dâru'l-Kütüb, 1413/1993), 257. Nesh, istisna ve tahsis kavramlarının birbirlerinden farkı için bk. Gazzâlî, el-Mustasfâ, thk. Muhammed Abdüsselâm, 257.

Râzî, "Enf", thk. Yusuf Șeyh Muhammed, 23.

İsmail Durmuş, "İstînâf", Türkiye Diyanet Vakfi İslam Ansiklopedisi (Ankara: TDV Yayınları, 2001), $23 / 367$.

el-En'âm 6/80.

el-A'râf 7/188

Ebü'l-Ferec Abdurrahman b. Ali b. Cevzî, Nüzhetü'l-a'yüni'n-nezâir, thk. Muhammed Abdülkerim (Beyrut: Müessesetü'r-Risâle, 1404/1984), 125. 
İnşallah teriminin eşanlamlısı olan kelimelerden birisi de "bi-iznillâh" (بإِذن الله) kelimesidir. "Bi-iznillâh", Türkçe'de "Allah'ın izniyle" demektir. Bu kelime ile inşallah kelimesi arasında herhangi bir anlam farklılığ olmayıp bunlar birbiri yerine kullanılan eşanlamlı kelimelerdir. ${ }^{99}$ Her ikisi de bir fiilin gerçekleşmesinin Allah'ın iradesine bağlı olmasını ifade etmektedir. Bir kulun, fiilini Allah'ın izniyle gerçekleştirmesi Allah'ın irade ve kaderî tekvin sıfatlarıyla bağlantısını göstermektedir. Bunlar ise bir ilâhta bulunması zorunlu sıfatlardandır. ${ }^{100}$

"Bi-iznillâh" kelimesinin inşallah kelimesiyle aynı anlama geldiği bazı âyetlerde de görülmektedir. Meselâ "Allah, bir insanla ancak vahiy yoluyla yahut perde arkasından konuşur. Yahut bir elçi gönderip, izniyle ona dilediğini vahyeder. Şüphesiz 0 yücedir, hüküm ve hikmet sahibidir"101 âyeti ile "Göklerde nice melekler vardır ki onların șefaatleri; ancak Allah'ın izniyle, dilediği ve hoşnut olduğu kimselere yarar sağlar"102 âyetinde geçen Allah'ın dilemesi ve izin vermesi, yani "inşallah" ve "biiznillâh" kelimeleri aynı anlam ekseninde birleşmektedir.

Örfî istisnanın başka bir anlamdaşının "meşîetullâh" (مشيئة الهُ) ve "irâdetullah" (إرادة الله)olduğu ifade edilebilir. Gerçi "meşîetullah" ve "irâdetullah" kelimelerinin inşallah anlamına geldiği daha önce belirtilse de burada "harf-i cerli" kullanımına dair bir pasaj açmakta yarar vardır. Bu bağlamda "bi-meşîetillah" (بمشيئة اللها (بالة) "li-meşîetillah"

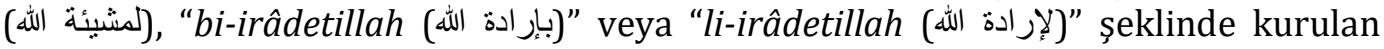
istisna aynen örfî istisna gibi amel etmektedir. Meselâ bir koca, eşine: "Sen boşsun bimeşîetillah" veya "Sen boșsun li-meşîetillah" dediğinde talâk aynen örfî istisnada olduğu gibi vâki olur. Aynı hüküm "bi-irâdetillah" ve "li-irâdetillah" kelimeleri için de geçerlidir. ${ }^{103}$

Örfî istisna Allah'ın dışındaki varlıklar için de kullanılabilir. Böyle bir kullanımda "Sen dilersen" anlamına gelen "mâ şi'te" (ما شئت) veya "in şi'te" (إن شئت) cümleleri örnek olarak ileri sürülebilir. Bir kimse başkasına: "Sana dilediğin şeyi veya buna benzer şeyleri veriyorum" derse böyle bir cümle kişinin dilediği miktardaki bir şeye bağlı (mevsûl) olabileceği gibi istediği zaman bu nimete nâil olacağına da bağlı olabilir. Bu kural bir kocanın, eşine: "Sen boşsun dilediğin gibi" șeklinde bir cümleye de bağlanabilir. Bu durumda kadın boşama sayısı konusunda birden üçe kadar serbest olabildiği gibi boşamayı fevrî (hemen) veya terâhî (daha sonra) olarak dilediği zaman diliminde de kullanabilir. ${ }^{104}$

Keza koca, boşama fiilini üçüncü bir şahsın dilemesine bağlarsa o şahıs öğrendiği mecliste boşama yetkisini temlik edebilmektedir. Hatta o şahıs, "şâe" (شاءa)

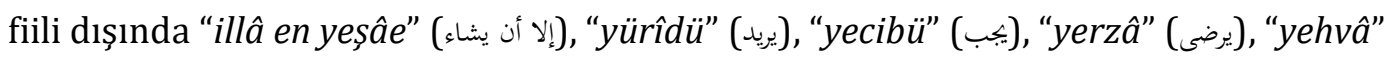

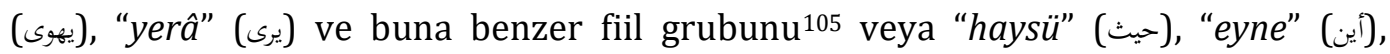

\footnotetext{
Muhammed Tahir b. Âşur, Tahrîrul'-ma'nâ's-sedîd (Tunus: Dâru't-Tunusî, 1404/1984), 15/296. Berhâmî, el-Furkān, thk. Abdurrahmân b. Abdilkerîm, 197. eş-Şûrâ 42/51. en-Necm 53/26. Kefevî, Külliyyât, 75 . Abdürrahim b. Ali İsnevî, el-Kevkebü'd-dürriyye, thk. Hasan Avvâd (Amman: Dâru Ammâr, 1405/1984), 214.

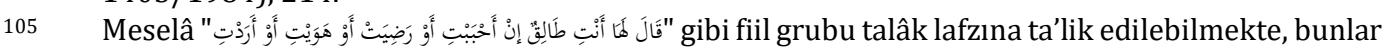
tıpkı "إنْ بَشْتَ" gibi kalbî fiillerden sayılmakta ve aynı işlevi ifa etmektedirler. Kâsânî, Bedâiu'ssanâi', 3/121.
} 
"eynemâ" (أينما) ve "haysümâ" (حيثما) gibi ism-i mekânlar1106 boşama hususunda örfî istisna olarak kullansa, kalbiyle meşîet ve rızâ olmaksızın diliyle haber verdiği için belirlenen meclisle kayıtlı olmak şartıyla boşama gerçekleşebilir. Zira meşîet ve sözü geçen her bir fiil, gizli bir emir anlamı taşımaktadır.107

Örfî istisna, meşîeti kendisine bağlı olmayan insanların dışındaki Cibrîl, melekler, cinler ve şeytanlar gibi varlıklara ta'lik edilirse tıpkı Allah'a ta'lik edilmiş gibi olmakta ve aynı sonuçları doğurmaktadır. ${ }^{108}$ Fakat İbn Kayyim el-Cevziyye bu görüşe karşı çıkmış, sözü geçen varlıkların meşîeti ile Allah'ın meşîetinin benzer olmadığına ve yapılan kıyasın yanlışlığına dikkat çekmiştir. Hele hele taş, ölü, müzmin deli olan kimselerin ve Allah'ın lâneti üzerine olan şeytan gibi bir mahlûkun örfî istisnanın içeriğinde zikredilmesi ve Allah'ın meşîetiyle bir tutulmasından daha feci ve kötü bir olayın olmadığını ileri sürmüştür. ${ }^{109}$

Allah'ın dıșındaki varlıklar nazarında hal böyle iken, Allah nazarında örfî istisna "şâe" (شاء) ve ondan müştak sîgalarla kullanılabildiği gibi aralarında herhangi bir anlam ve görev farkı olmayan ve dileme (isteme) anlamına gelen başka fiillerle de kullanılabilir. ${ }^{110}$ Çünkü bütün fiiller sıfat-ı ilâhîde eș anlam statüsündedir. Bu özellik sadece örfî istisnanın Allah'a hasredilmesinde söz konusudur. Sifat-ı beşerde dileme ve isteme fiilleri farklı anlamlar barındırdığından dileme ile sarf edilen örfî istisna bağlayıcı; isteme ile sarf edilen örfî istisna ise bağlayıcı değildir. Çünkü daha önce de değinildiği gibi dileme fiili, var olan şeyi haber verdiği, isteme fiili ise nefsin meylettiği, var olmayan şeyleri haber verdiği veya aniden ortaya çıtığı için böyle bir hüküm ortaya çlkmaktadır.111

\subsection{Sonuçları}

Daha önce de zikredildiği gibi örfî istisnanın geçerli olması birtakım şartları taşımasına bağlıdır. Şartları taşımayan her bir örfî istisna bâtıl olmaktan öteye gidememektedir.112 Örfî istisna şartları gerçekleștiğinde ise birtakım hukuki sonuçlar doğurabilir. Bu sonuçlardan birisi ister akdin kurulmasından sonra akdin bozulması şeklinde, isterse akdin kurulmasını en başta menetmek şeklinde olmak üzere kendinden önce gelen hükmü iptal etmesidir. Meselâ yemin eden kimse yemininden sonra örfî istisna yapsa yeminin tamamlanmasından sonra istisnaya niyet etmeye cevaz verenlere göre bu istisnayla yemin bozulmuş olur. Yeminini bitirmeden önce yemin etmeye niyetlenen, sonra da örfî istisnayı zikreden kişinin yaptığı yemin de kabul görmez.113 Üstelik Allah'ın adı veya yüce sıfatlarıyla bir şey üzerine yemin

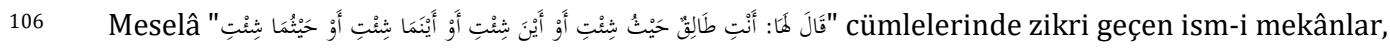
talâk hususunda herhangi bir mekâna bağlı olamama ve aralarında bir bağ bulunmama gereğince

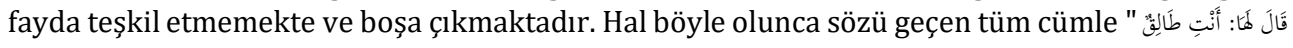
إِنْ شُنْبِ" formatına dönmektedir. Kâsânî, Bedâiu's-sanâi', 3/121.

107 İbnü'l-Hümâm, Fethü'l-kadîr, 4/136.

108 Kâsânî, Bedâiu's-sanâi', 3/ 159-60; Semerkandî, Tuhfetü'l-fukahâ, 2/194.

109 İbn Kayyim el-Cevziyye, İlâmü'l-muvakkıîn, 5/ 477. İmam Şâfîi, İmam Mâlik ve Ahmed b. Hanbel de farklı gerekçelerle burada talâkın vâki olacağını savunmuşlardır. Vizâratü’l-evkāf, "Meşîet", $37 / 345$.

110 Meselâ " gibi kelimeler de örfî istisnanın yaygın olarak kullanıldığı lafızlardır. Kâsânî, Bedâiiu's-sanâi', 3/27. İbnü'l-Hümâm, Fethü'l-kadîr, 4/104.

Kurtubî, el-Câmi', thk. Ahmed Berdûnî, 6/274.

Vizâratü'l-evkāf, "İstisna", 3/195. 
yapıldığında bundan hiçbir kaçış söz konusu değildir. Ancak kişi sarf ettiği yemininden sonra sadece örfî istisnayı telaffuz eder veya bereketlenme (teberrük) amaçll: "inşallah" derse "Her kim yemin eder, ardından inşallah derse yeminini bozmamıș olur"114 hadisine binaen yemininden çıkıș yolu hâsıl olur. 115

Örfî istisnanın "Allah'a yemin olsun ki yemek yemeyeceğim, su içmeyeceğim inşallah" gibi atıf cümlelerinden sonra gelmesi durumunda mevcut hükmün, cümlenin tamamını kapsayıp kapsamayacağı noktasında ulemâ arasında ittifak vardır. Çünkü inşallah kelimesi söz konusu cümlede şart konumunda olup, istisnanın hakikatinden sayılmamaktadır. Mamafih nahivciler bir şart takdiren cümlenin başına geçebildiği için kelamın şartla başlamasında bir sakınca görmemektedirler. Hâlbuki istisna ister lafzî isterse takdirî olsun cümlenin sonlarında bulunması iktiza eder.116 Konuya farklı bir açıdan yaklaşan Serahsî (ö. 483/1090) ise, örfî istisnanın ikrarla ilgili bir kelamda söylenmesi durumunda cümleyi "azîmet"117 olmaktan çlkarıp şart anlamına nakletmektedir. Nitekim Allah'ın, Hz. Mûsâ'nın verdiği sözde sabırsızlığını beyan için “Mûsâ: 'İnşallah beni sabırlı bulacaksın. Hiçbir işte de sana karşı gelmeyeceğim' dedi"118 âyetini zikretmesi bu hususu vurgulamak amacıyladır.

Hanefî ve Şâfiîler örfî istisnanın kavlî tasarruflarla beraber kullanılması durumunda bu tasarrufların örfî istisna tarafından menedileceğini ileri sürerler. Hatta Hanefîler böyle bir istisnanın hükmünün "inşaî" sîga da olsa "ihbarî" olduğunu; 119 ancak emir ve nehiy sîgalarıyla kullanıldığında hükmün sabit olmayacağını iddia ederler. Söz gelişi bir kimse: "Vefatımdan sonra falanca kimseye malımın üçte birini verin inşallah" diyerek vasiyette bulunsa istisna emir cümlesinde bulunduğu için bâtıl, vasiyet ise geçerlidir.120 Keza ölüm hastalığına (maraz-ı mevt) yakalanan bir kimse: "Ölümümden sonra kölemi azat edin inşallah" veya "Kölem ölümünden sonra hürdür inşallah" derse birinci cümlede örfî istisna, emir cümlesinde mevcut olduğundan bâtıl, vasiyet geçerli; ikinci cümlede istisna, bir icap cümlesinde bulunduğundan amel ettiği için geçerli, vasiyet ise sahih olmamaktadır. ${ }^{121}$ Buna karşılık Mâlikî ve Hanbelî mezhebiyle, Evzâî, Hasan el-Basrî ve Katâde (ö. 117/735) gibi fakihler ise örfî istisnanın yeminler dışında kalan tüm tasarrufların kuruluşuna mâni teşkil etmediğini savunurlar. Şu kadar var ki, bir kimse: "Benim zimmetimde ona ait bin dirhem vardır inşallah veya Allah hükmederse" derse kendisine bin dirhem vermek lazım gelir. Çünkü bir kimse bir şeyi ikrar ettiği zaman Allah'ın onu dilemesi

114 Tirmizî, "en-Nüzûr ve'l-eymân", 7 (No. 1532).

115 Karâfî, ez-Zehîre, 4/22.

116 Muvaffakuddîn Abdullah b. Ahmed b. Kudâme, Ravzatü'n-nâzır ve cünnetü'l-münâzır (b.y.: Müessesetü'r-Reyyân, 1423/2002), 2/ 96-97.

117 Kelam, lağv ve azimet olmak üzere iki çeşittir. Lağv, boş sözler; azimet ise üzerine kesin karar verilen sözlerdir. Ebû Bekr Șemsü'l-eimme Muhammed es-Serahsî, el-Mebsût (Beyrut: Dâru'lMârife, 1414/1993), 17/191.

118 el-Kehf 18/69.

119 İnşâ, söylenmesiyle aynı anda bir fiil gerçekleştirmiş olan ifadedir. İhbâr ise mâzide meydana gelen ve gelecekte vuku bulacak bir olayı ilan etmektir. Aralarında sımsıkı bir ilişki bulunan bu iki kavram bazen birbirlerinin yerine geçebilmekte, ihbarî bir ifade inşaî olabilmektedir. Meselâ bir koca eşine: "Ayağa kalkarsan boşsun" derse bu ifade artık haber cümlesi olmaktan çıkıp bir inșaî cümle olmaktadır. Ali İhsan Pala, İslâm Hukuk Metodolojisinde Emir ve Yasakların Yorumu (Ankara: Fecr Yayınları, 2009), 58-62.

120 İbnü'l-Hümâm, Fethü'l-kadîr, 4/136; İbn Âbidîn, Reddü'l-Muhtâr, 3/366; Vizâratü'l-evkāf, "İstisna", 3/196.

121 İbnü'l-Hümâm, Fethü'l-kadîr, 4/136; Ebü'l-Meâlî Burhânüddin Abdülazîz b. Mâze, el-Muhîtü'lburhânî, thk. Abdülkerim Sâmî (Beyrut: Dâru'l-Kütüb, 1424/2004), 3/282; İbn Âbidîn, Reddü'lMuhtâr, 3/689. 
veya nasip etmesi herkes tarafından olağan bilinir. 0 halde örnekte olduğu üzere örfî istisna yeminleri bozsa da bunun dişında kalan tüm akit ve tasarrufların kuruluşuna mâni olmaz. ${ }^{122}$

Diğer taraftan örfî istisna Allah adı dışındaki varlıkların isimleriyle ifa edilirse aksi bir husus ortaya çıkar. Bu istisna Allah'ın ismiyle yapıldığında ister varlık isterse yokluk üzere ta'lik edilsin, Allah'ın daima varlığı irade etmesi sebebiyle ikisinden birinin vâki olması kesin, mâlum ve zaruridir. Oysa başkalarının adıyla yapılan istisnalarda aynı şeyler mevcut olmamakta, haber olmaktan öteye gidemeyip kesin bir bilgi ifade edememekte, sonuçta zan seviyesinde kalıp bâtıl sayılmaktadır. ${ }^{123}$

Hanbelîler, herhangi bir konu üzerine yapılan yeminin örfî istisna ile bâtıl olduğunu, bunun dışında kalan akitlere örfî istisnanın tesiri olmadığını savunurlar. Meselâ bir kimse: "Sana bu malı sattım inşallah" veya "Sana bu malı hibe ettim inşallah" şeklinde bir cümle kursa her iki akit de sabit olur. Konu, talâk açısından düşünüldüğünde ise, Hanbelîlerdeki bir görüşe göre örfî istisna sözü geçen akitlerin yürürlüğünü durdurabildiği, diğer bir görüșe göre ise yapılan davranıșın yeminle ilgisi olmaması sebebiyle her iki akde de tesir etmediği şeklindedir. Meselâ bir kimse eşine: "Seni boşadım inşallah" derse insanların bu konudaki ihtilafı ve delillerin teâruzu nedeniyle örfî istisna bu akitlere hiçbir fayda sağlamaz. ${ }^{124}$

O halde buraya kadar anlatılan özet bilgi ve örneklerden örfî istisnanın gerekli şartları taşıdığında bazı akit ve tasarruflara tesir ettiği ve mezhepten mezhebe, fakihten fakihe değişen birtakım fıkhî hükümler doğurduğu sonucu çıkarılabilir. Bu sebeple konunun enine boyuna irdelenebilmesi ve fikhî hükümlerin daha kolay anlaşılabilmesi için örfî istisnayla ilgili kısımların farklı başlıklar altında detaylıca incelenmesinde yarar vardır.

\section{2. Örfî İstisnanın Bazı İbadet ve Akitlerdeki İzdüşümü}

Yapılan araştırmayla örfî istisnanın, İslâm fikhının tüm ahkâmında değil, bazı ibadet ve akitlerde tezahür ettiği ifade edilebilir. Tezahür ettiği alanlar ise ibadetler, nikâh, talâk, ikrar, yemin ve diğer tasarruflar şeklinde sıralanabilir.

\section{1. İbadet Ahkâmındaki Yeri}

İslâm hukukunda ibadetlere istisna ile başlamanın teşvik edildiği, onsuz ifa edilen ibadetlerin ise noksan kalabileceği ifade edilebilir. Nitekim bir müslümanın: "İşallah namaz kıldım, inşallah oruç tuttum" demesi, ifa edilen ibadetin Allah nezdinde kabul edilip-edilmediğinin bilinmemesi sebebiyle câizdir. Zira müminler yaptıkları iman ve ibadetlerinin Allah katında kâmil ve makbul olup-olmadığı noktasında bilinmezlik içerisindedirler. Bu sebeple iman ve ibadetlerde istisnanın kullanımına ihtiyaç duyulmaktadır. ${ }^{125}$

Konuya başka açıdan yaklaşan Hanefî fakih Halvânî (ö. 452/1060) dille tahsis edilen istisnanın talâk ve bey' gibi akitleri iptal ettiğini, ancak dille tahsisi mümkün olmayan "Yarınki oruca niyet ettim inşallah" örneğinde olduğu gibi ibadet türü amelleri ise lafzen iptal etse de niyet kalben yapıldığı için iptal edemediğini, bu tür

\footnotetext{
122 Düsûkī, Hâşiyetü'd-Düsûkī, 3/402.

123 Karâfî, el-Furûk, 1/ 77; Karâfî, ez-Zehîre, 4/79.

124 Muvaffakuddîn Abdullah b. Ahmed b. Kudâme, el-Muğnî (b.y.: Mektebetü Kahire, 1387/1968), 7/ 466.

125 Abdülaziz b. Abdullah İbn Bâz, Mecmûu Fetâvâ (b.y.: y.y., ts.), 5/403.
} 
ibadetin edasının böyle bir niyetle mümkün olduğunu dile getirmiștir. ${ }^{126}$ Ayrıca söz konusu örnekteki istisna, hakiki istisna değil, Allah'ın yardım ve muvaffakiyetini talep etme anlamına gelen örfî istisna olması nedeniyle de câizdir. ${ }^{127}$ Buna mukabil bazı ibadetlerde örfî istisnanın kullanılması, insanın Allah'a olan ihtiyacına şüphe düşürdüğü ve O'na tazimi tam manasıyla ifade etmediği veçhiyle câiz değildir. Meselâ iftitah tekbirinden önce namaza niyet sadedinde kişinin: "Allah'ım beni affet, Şeytanın şerrinden Allah'a sığınırım, Allah dilerse" gibi cümlelerle niyetlenmesi yukarıda geçen sebeplerden ötürü câiz değildir. ${ }^{128}$ Keza Şâfiîlere göre abdest alırken niyetin, abdestin başından sonuna kadar devam etmesi ve bu niyeti bozucu her türlü eylem ve sözden sakınılması önem arz eder. Bu minvalde kişi abdest ibadetini ifa ederken bereket ummak veya niyeti bozmamak amacı dışında "inşallah" derse niyetin devamı sağlanamadığı için abdest sahih değildir. ${ }^{129}$ Buradan hareketle örfî istisnanın ibadet ahkâmında önemli bir yere sahip olduğu ve bazı ibadetlerde teşvik edilmesine karşın bazı ibadetlerde câiz olmadığı iddia edilebilir.

Dualardaki yansımasına gelince, örfî istisnanın dualarda kullanılması haramdır. Çünkü Hz. Peygamber'in “Sizden biriniz 'Allah'ım inşallah beni bağışla, inşallah bana merhamet et, inşallah beni rızıklandır' demesin ve dileğini ısrarla istesin. Çünkü Allah'ı zorlayacak hiçbir güç yoktur"130 şeklindeki sahih hadisi buna işaret etmektedir. Bu şekilde ifa edilen dua, kulun Allah'a muhtaçlığını izhar etmeme ve onsuz yapabileceğini hissettirme anlamları taşımaktadır. Böyle taleplerin hâsıl olması Allah'a karşı saygısızlık ve şer'î kurallara aykırılık teşkil etmesi nedeniyle imkânsızdır. ${ }^{131}$

\subsection{Nikâh ve Talâk Ahkâmındaki Yeri}

Örfî istisnaya çokça başvurulan alanlardan birisi de nikâh ve talâk ahkâmıdır. Bir erkeğin evlenmek istediği bir kadına "Seninle evlendim sen dilersen" ya da "Zeyd dilerse" örneğinde olduğu gibi nikâh akdini örfî istisnaya ta'lik etmesi durumunda nikâhının sahih olup-olmadığı ulemâ arasında tartışılmıştır. Hanefîler nikâha örfî istisnanın ta'lik edilmesi durumunda istisna sahibi aynı mecliste ileri sürdügü istisnayı iptal ederse nikâhın sahih olduğunu, çünkü yapılan iptalle nikâhın örfî istisnaya ta'lik edilmemiş bir hale geldiğini savunmuşlardır. Keza onlar, bir erkek, evlenmeyi düşündüğü kadına: "Seninle evlendim dilersen" dedikten sonra kadın herhangi bir şart sunmaksızın: "Kabul ettim" şeklinde cevap verirse kabulün, bir nevi meşîet sayılması sebebiyle istisnanın iptaline gerek kalmaksızın nikâhın sahih olduğunu da ifade etmişlerdir. Şâfiîler bir erkek, kadına: "Seninle evlendim inşallah" şeklinde bir söz sarf eder, bununla da ta'lik veya boşamayı kastederse nikâhın sahih olmadığını; ancak bununla bereketi ve her şeyin Allah'ın meşîetiyle meydana geldiğini kastederse nikâhın sahih olduğunu belirtirler. Hanbelîler ise karşı tarafın da aynı şekilde kabulü şartıyla nikâhı sahih kabul etmişlerdir. ${ }^{132}$

\footnotetext{
126 İbnü'l-Hümâm, Fethü'l-kadîr, 4/136; İbn Âbidîn, Reddü'l-Muhtâr, 3/366.

127 İbn Mâze, el-Muhîtü'l-burhânî, 3/380, 382.

128 İbn Mâze, el-Muhîtü'l-burhânî, 1/293.

129 Vizâratü'l-evkāf ve'ş-şüûni'l-islâmiyye, "Vudû", Mevsûatü'l-fikhiyye, (Kuveyt: Dâru's-Selâsil, 1427/2006), 43/ 330.

130 Buhârî, "Tevhîd", 31 (No. 7477).

131 Karâfî, el-Furûk, 4/285-86.

132 İbnü'l-Hümâm, Fethü'l-kadîr, 3/198; Şemsüddîn Muhammed b. Ahmed el-Hatîb eş-Şirbînî, Muğni'l-muhtâc (Beyrut: Dâru'l-Kütüb, 1414/1994), 4/ 231; Mansûr b. Yûnus b. Salâhuddîn elBuhûtî, Keşşâfü'l-ḳınâ' (Beyrut: Dâru'l-Kütüb, ts.), 5/40.
} 
Nikâh akdi, "Seni kızımla evlendireceğim ayın bașı gelirse" veya "Annesi izin verirse" veyahut "Falanca razı olursa" gibi meşîetin dışında istikbale yönelik bir şartla kayıtlanarak yapılırsa nikâhın gerçekleșmesi ivazlı akitler gibi belirtilen şartlara bağlı olduğu ve bunun da nikâhın ruhuna aykırılık teşkil ettiği veçhiyle sahih değildir. ${ }^{133}$

Konu, talâk ahkâmına gelince örfî istisnanın amel edebilmesinin kelama muttasıl olmasına bağlı olduğu daha önce belirtilmişti. Bu şart talâkta da kendini göstermektedir. Talâk lafzının cümlede örfî istisnadan önce veya sonra gelmesinde herhangi bir mahzur yoktur. ${ }^{134}$ Bu bağlamda bir kimse eșine: "Sen boşsun" der, sonra bir miktar sükût ettikten sonra: "üç defa inşallah" derse, bu sükût nefesin kesilmesinden kaynaklanmış ise üç talâk, kaynaklanmamışsa bir talâk vâki olur. Aynı durum teneffüs etmekten veya eli ağızdan kaldırmaktan kaynaklı ise af kapsamında değerlendirilir. ${ }^{135}$ Ancak talâk konusunda örfî istisna yaparken kişinin ağzı başkası veya eşi tarafından belli bir zaman kapatılır, sonra onu bıraktığında o kişi örfî istisnayı zikrederse istisna sahih olduğu için talâk geçersiz; zikretmezse istisna sahih olmadığı için talâk vâki olur. ${ }^{136}$

Örfî istisnalı bir kelamda talâk, bir mektup veya mesajla ifa edilirse yine muttasıl olma şartı aranır. Gıyaben kaleme alınan yazılı materyaller tıpkı aynı ortamda ifade edilen sözler mesabesinde kabul edildiğinden örfî istisna kelama muttasıl olursa istisna geçerli, talâk geçersiz; muttasıl olmazsa istisna geçersiz, talâk geçerli olur. ${ }^{137}$

Örfî istisna içeren bir talâkta boşama sayısı küçükten büyüğe doğru tekmil edici bir sıralama ile olursa üç talâk, büyükten küçüğe doğru olursa talâk geçersiz olur. Şöyle ki, bir kimse eșine: "Sen bir defa ve üç defa boşsun inșallah" diyerek cümle kurarsa boşama tekmil edici özelliğe sahip olduğu için talâkın üçü de vâki olurken; "Sen üç defa ve bir defa boșsun inşallah" diyerek cümle kurarsa boşama, boş sözden ibaret olduğu için geçersizdir. ${ }^{138}$ Keza koca, eşine: "Sen üç, üç defa boşsun inşallah" diyerek kelam ile örfî istisna arasına teyit etmek için boşama sayısını ilave ederse Ebû Hanife'ye göre ikinci kelime boş olduğu (lağv) ve kelam ile istisna arasında fâsıla meydana getirdiği için istisna bâtıl, talâk geçerli; İmâmeyn'e göre ise kelamın örfî istisnaya açık bir şekilde mevsul (bitişik) olması sebebiyle istisna sahih, talâk geçersizdir. ${ }^{139}$

Koca, boşama yetkisi konusunda eşine örfî istisna kullanarak vekâlet verirse hangi şartı koyduysa kadının o şarta uyması önem arz etmektedir. Meselâ koca, eşine: "Dilersen kendini üç defa boşa" şeklinde hitap ettikten sonra kadın, kendini bir defa boşarsa üç defa boşama şartı yerine gelmediği için boşama hükmü gerçekleşmez. Keza koca, eşine: "Dilersen bir defa kendini boşa" dedikten sonra kadın, kendini üç defa boşarsa Ebû Hanîfe'ye göre bir önceki kaideye binaen boşama gerçekleşmezken; İmâmeyn'e göre kadının üç boşamayı dilemesi, bir boşamayı dilemesi demek olduğu ve ileri sürülen şart yerine getirildiği için boşama vâki olur. ${ }^{140}$

\footnotetext{
133 Vizâratü'l-evkāf ve'ş-şüuni'l-islâmiyye, "Nikâh", Mevsûatü'l-fikhiyye (Kuveyt: Dâru's-Selâsil, 1427/2006), 41/309.

134 Kâsânî, Bedâiu's-sanâi', 3/157.

135 İbn Âbidîn, Reddü'l-Muhtâr, 3/367.

136 İbnü'l-Hümâm, Fethü'l-kadîr, 4/139.

137 İbn Mâze, el-Muhîtü'l-burhânî, 3/276

138 İbn Âbidîn, Reddü'l-Muhtâr, 3/367.

139 Serahsî, el-Mebsût, 18/90.

140 İbnü'l-Hümâm, Fethü'l-kadîr, 4/103.
} 
Talâk, tarafeyn tarafından birbirlerinin dilemelerine bağlanırsa bâtıl olur. Meselâ bir koca, eşine: "Sen boşsun dilersen" dedikten sonra kadın: "Ben boşamayı diliyorum, sen dilersen" derse, koca da: "Boşamaya niyet ederek diliyorum" dese kocanın, boşamayı kadının dileğine, kadının da kocanın dileğine bağlaması sebebiyle şart gerçekleşmez. Dolayısıyla şartın alakasız birtakım şeylerle iştigal edilmesi ve sonuçta boşama yetkisinin kadının elinden çıkması veçhiyle boşama bâtıl olur. ${ }^{141}$ Lâkin koca, eșine: "Sen boșsun dilersen" dedikten sonra kadın: "Ben bu, gece veya gündüz olursa ya da bu, babam, annem veya eșim olursa" diyerek örfî istisnasını mevcut olan bir şeye ta'lik ederse talâk meydana gelir. Çünkü bu husus, mevcut bir şarta ta'lik edilmiş olmakta, mevcut bir şartın da geçerliliği sahih kabul edilmektedir. ${ }^{142}$

Örfî istisna kendisiyle talâkı veya kazf haddini gerektirici bir cümle içerisinde kullanılırsa farklı görüşler bulunmakla beraber istisna sadece o zikredilen şey için geçerli, kendisiyle talâkı veya kazf haddini gerektirici bir cümle içerisinde kullanılmazsa cümlenin tamamı için geçerlidir. Meselâ bir kimse eşine: "Ey zinakâr kadın veya ey boş olan kadın! Sen üç talâk ile boşsun inşallah" dediğinde örfî istisna zinakâr veya boş olan kadın hakkında vâki olur. Buna karşın koca: "Ey habis kadın! Sen üç talâk ile boşsun inşallah" dediğinde örfî istisna tüm cümle için vâki olur. ${ }^{143}$

Örfî istisna sırasıyla hem ric'î hem de bâin talâkın zikredildiği bir cümle içerisinde bulunursa o kişiye hangisini kastettiği sorulur. Ric'î talâka niyetlenmişse ric'î talâkla istisna arasına fâsıla girdiği için istisna geçersiz, talâk vâki olur. Şayet bâin talâka niyetlenmişse bâin talâkla istisna muttasıl olduğundan istisna amel eder, bâin talâk geçersiz olur. Konuyu örnek üzerinde değerlendirmek gerekirse, bir koca eşine: "Sen ric'î veya bâin talâkla boșsun inșallah" șeklinde bir söz sarf ederse niyetinin kendisine sorulması neticesinde ric'î talâka niyetlenmişse ric'î talâkla istisna arasına bâin talâk lafzı girdiğinden istisna amel etmemekte ve talâk gerçekleşmektedir. Bâin talâka niyetlenmişse sözle istisna muttasıl olduğundan istisna, bâin talâkı iptal etmektedir. ${ }^{144}$

Kocası tarafından boşamaya maruz kalan kadının veya boşamaya yeltenen kocanın örfî istisna sözünden önce vefat etmesi durumunda örfî istisnanın ölüme muttasıl olup-olmaması noktasında birtakım hükümlerin ortaya çıkması da bu kapsamda düşünülebilir. Bir koca eşine: "Sen boșsun" dedikten sonra "inşallah" sözünü sarf etmeden kadın vefat ederse kadının vefatı ta'like; yani örfî istisnaya zıtlık teşkil etmez. Buradaki olay talâk değil, ta'likin kendisidir. Ta'lik nasıl hükme tesir edip onu iptal edebiliyorsa, ölüm de hükme tesir edip onu iptal edebilmektedir. Her ikisi de hükmü iptal etme hüviyetine sahip olmaları yönüyle birbirlerine eşittirler. Binaenaleyh bu cümlede istisna sahih olduğu için talâk gerçekleşmez. Diğer taraftan konu, kocanın vefatı açısından düşünüldüğünde ise yukarıdaki hükmün tersine bir durum ortaya çıkar. Şöyle ki, kocanın ölümü ile örfî istisna muttasıl değildir. Kocanın talâktan önce istisnayı kadına söylemek istediği herkesin mâlumudur. Hal böyle olunca ölüm ile istisnanın arası muttasıl olmaması ve istisnanın amel etmemesi nedeniyle talâk bilfiil gerçekleşir. ${ }^{145}$

\footnotetext{
141 İbnü'l-Hümâm, Fethü'l-kadîr, 4/103; Kâsânî, Bedâiu's-sanâi', 3/122.

142 Kâsânî, Bedâiu's-sanâi', 3/ 122.

143 İbn Âbidîn, Reddü'l-Muhtâr, 3/284, 367.

144 İbn Âbidîn, Reddü'l-Muhtâr, 3/368.

145 İbn Âbidîn, Reddü'l-Muhtâr, 3/368.
} 


\section{3. İkrardaki Yeri}

Bazı fakihler tarafından örfî istisnanın yeminler dıșında kalan tüm tasarrufların kuruluşuna mâni teșkil etmediği daha önce ifade edilmiști. Bu meyanda bir kimse: "Benim zimmetimde ona ait bin (dirhem) vardır inşallah" derse ona bin (dirhem) vermesi lazım gelir. Çünkü ikrar, gerçekleşmiş olan şeyin haberidir. Gerçekleşen şey ise kendisine birtakım şartların ta'lik edilmesini kabul etmez. ${ }^{146}$ Buna karşın İmam Şâfiî, örfî istisna nasıl talâk, köle âzadı ve yeminde etkin bir rol oynuyorsa ikrar cümlesinde de aynı etkinliğe sahiptir. Bu meyanda kiși: "Sana olan borcumun tamamını ödedim Allah dilerse veya falanca dilerse" dediğinde zikri geçen gerekçe sebebiyle istisna sahih, ikrar ise bâtıldır. ${ }^{147}$ Aynı düşünceyi gerekçesi farklı olmakla beraber Hanefîler de savunmaktadırlar. Onlara göre daha önceden olmuş bir şeyi ihbar etmek anlamına gelen ikrara örfî istisna ta'lik edilirse ihbar edilen şey muhtemel anlama dönüşmekte, böyle bir şey ise mümkün görünmemektedir. ${ }^{148}$

Hanbelîler diğer mezheplerden farklı olarak ikrarı, Allah'ın ve insanların meşîetine ta'lik edilmesi şeklinde iki kategoriye ayırmışlardır. Bir işin Allah'ın meşîetine bağlanması, ona şart koşulması değil, bereket için onun olurunun alınması demektir. Meşîet-i ilâhî ancak istenen işin vukuuyla bilinir. Dolayısıyla işin varlığı üzere durması mümkün değildir. Oysa insanın meşîetinin vukuu kolayca bilinebildiği için istenen işin vukuu şart olarak ileri sürülebildiği gibi istikbale de taayyün edebilir. Sonuçta bu husus ikrar değil, bir vaat olarak ortaya çıkar. Binaenaleyh bir kimse diğerine: "Benim sana bin (dirhem) borcum olsun eğer dilersen veya Zeyd dilerse" derse az önceki geçen gerekçe ışığında bu ikrar sahih olmamaktadır. Başka bir görüşe göre ise ikrarın, ister Allah'ın isterse başkasının meşîetine ta'lik edilmesi durumunda onun hükmünü kaldırıcı şeyi hemen ardından zikretmesi sebebiyle ikrar sahih olur. Başka bir ifadeyle güya kişi önce ikrar etmiş, sonra da ikrarından dönmüş sayıldığı için yaptığı rücu sahih değildir. ${ }^{149}$

\subsection{Yemindeki Yeri}

Örfî istisnanın belki de en fazla kullanıldığı alan yemin ahkâmıdır. Zira örfî istisna, bir nevi kefâret addedildiği için yemin içeren cümlelerde kullanımının câiz olması ${ }^{150}$ insanlar tarafından sıkça başvurulmasına sebep olmuştur. Bu hususta önemli olan, yemin eden kişinin neye niyet ettiğidir. Meselâ bir birey: "Vallahi (Allah'a yemin olsun ki) bunu yapmayacağım inşallah" diye yemin eder, akabinde niyet ettiği şeyi yaparsa, niyeti örfî istisna ise kefâret gerekmezken; niyeti "Ancak, "Allah dilerse yapacağım" de. Unuttuğun zaman Rabbini an ve "Umarım Rabbim beni, bundan daha doğru olana ulaştırır" de"151 âyetindeki örfî istisnaya vurgu değilse yeminini bozmuş olur. ${ }^{152}$

Yemin eden bir kimsenin yemin cümlesinde ister alenen isterse gizlice örfî istisnayı söylemesi durumunda yaptığı yemin bozulduğuna göre bir kimse bir

146 Karâfî, ez-Zehîre, 9/303.

147 Ebü'l-Hasan Ali b. Muhammed Habib el-Mâverdi, el-Hâvi'l-kebîr, thk. Ali Ma'vez (Beyrut: Dâru'lKütüb, 1419/1999), 18/287.

148 Vizâratü'l-evkāf ve'ş-şüuni'l-islâmiyye, "İkrâr", Mevsûatü'l-fikhiyye (Kuveyt: Dâru's-Selâsil, 1427/2006), 6/64.

İbn Kudâme, el-Muğnî, 5/161; Vizâratü'l-evkāf, "İkrâr", 6/65.

Sahnûn, el-Müdevvene, $1 / 584$.

el-Kehf 18/23-24.

Sahnûn, el-Müdevvene, 1/584. 
başkasına yemin ettirir, akabinde gizlice örfî istisnayı söylemesinden korkarsa ona açıtan yemin ettirir ve yeminin hemen ardından "Sübhânallâh" demesini kendisinden isteyebilir. ${ }^{153}$ Böylelikle yeminin bozulmasının önüne geçilebilir.

Anlam yönünden birbirinden farklı yemin cümlelerinden sonra bir defa örfî istisna zikredildiğinde bu istisna cümlenin tamamına şamil olmakta ve yapılan yeminleri iptal etmektedir. Meselâ bir kimse: "Allah'a yemin olsun ki yemek yemeyeceğim, eve girmeyeceğim ve Zeyd ile konuşmayacağım inşallah" șeklinde bir cümle kurarsa, örfî istisna cümlenin tamamını kapsamakta ve yapılan üç yeminin de hükmünü bertaraf etmektedir. ${ }^{154}$

Zıhâr yemini bazen örfî istisna ile kullanılabilir. Zıhâr, bir kocanın, eşini kendisine ebediyen haram olan kadınlardan birisinin uzvuna benzetmesidir. 155 Cumhura göre böyle bir yemin kocanın, eșine: "Sen bana anamın sırtı gibisin inşallah" şeklinde ifade edilirse hiçbir şey lazım gelmezken; "Sen bana anamın sırtı gibisin falanca dilerse" veya "sen dilersen" şeklinde olursa zihâr yemininin büyük bir cinayet olması sebebiyle bu yeminle koca ile kadın arasında haramlık vâki olmakta, ancak kefâretle bu hüküm kalkmaktadır. ${ }^{156}$

Îlâ yeminindeki örfî istisnadan da burada bahsedilebilir. Îlâ yemini bir kocanın, eşine yaklaşmamaya yemin etmesidir. ${ }^{157}$ Örfî istisnayla irtibatına gelince Hanefîlere göre bir koca, eşine: "Sen eğer dilersen Allah'a yemin olsun ki sana yaklaşmayacağım" dedikten sonra kadın da bunu dilerse aynı mecliste olmak şartıyla îlâ yemini gerçekleşir. Aynı hüküm üçüncü bir şahısla istisnada da söz konusudur. Hanbelîlere göre kadın başka bir mecliste de dilerse îlâ yemini meydana gelir. Ancak kadının dışındaki üçüncü şahısların istisnası söz konusu olursa îlâ yemini bâtıl olur. Şâfiîlere göre ise örfî istisna direkt muhatap olan kadına arz edilir, o da bunu dilerse îlâ yemini fevrî olarak gerçekleşirken, kadının dışındaki dolaylı muhataplarda şahıslar dilese bile îlâ yemini muteber olmaz. ${ }^{158}$

\subsection{Diğer Tasarruflarda Örfî İstisna}

Gündelik yaşamda insanların istisnayı kullanma zarureti yoktur. Meselâ bir kimsenin: "İnşallah sattım, inşallah gittim, inşallah yaşadım" gibi cümleler sarf etmesi, Allah'ın iradesine örfî istisnanın ta'lik edilmesini gerektirmez. Çünkü bu gibi söz ve fiiller sıradan şeyler olup başlaması ve bitmesi herkes tarafından idrak edilebilmekte ${ }^{159}$ ve inşaî ve ihbarî cümleler olmadığı için bu istisnalar ulemâ arasında kabul görmemektedir. ${ }^{160}$ Buna karşın meselâ bir kimse: "Ben bunu sattım inşallah"

\footnotetext{
153 İbnü'l-Hümâm, Fethü'l-kadîr, 4/139.

154 Cüveynî, et-Telhîs fî usûli'l-fikh, thk. Abdullah Nebâlî, 2/ 84; Gazzâlî, el-Mustasfâ, thk. Muhammed Abdüsselâm, 260.

155 Râzî, "Zhr", thk. Yusuf Şeyh Muhammed, 197.

156 İbnü'l-Hümâm, Fethü'l-kadîr, 4/ 247; Vizâratü'l-evkāf, "Meşîet", 37348.

157 Kefevî, Külliyyât, 223.

158 İbn Kudâme, el-Muğnî, 7/542; Ebû Zekeriyyâ Yahyâ b. Şeref b. Mürî en-Nevevî, Ravzatü't-tâlibîn, thk. Züheyr Şâvîş (Beyrut: Mektebetü'l-İslâmî, 1411/1991), 8/244; Kâsânî, Bedâiu's-sanâi', 3/ 131.

159 İbn Bâz, Mecmûu Fetâvâ, 5/403.

160 İbn Kayyim el-Cevziyye, İ'âmü'l-muvakkıîn, 5/475.
} 
derse Allah'ın bu satışı ezelde dilemesiyle şartın tahakkuk etmesi, bu şartın da var olmayı lazım kılan bir sebep olması nedeniyle bu satış icmâen geçerlidir.161

İslâm fıkhında bir kimse başkasını kendi adına bazı tasarruflarda bulunması için vekil tayin edebilir. Vekil kendisine verilen vekâlet çerçevesinde birtakım tasarruflarda bulunabilir. Meselâ bir koca vekiline: "Benim eşimi boşa" dediğinde vekil, konuşmanın geçtiği mecliste o kadını boşayabildiği gibi sonrasında da boşayabilir. Vekâlet verme (tevkîl) bir nevi yardım isteme kabul edildiği, bu sebeple bağlayıcı olmadığından koca, verdiği vekâletten her zaman ve zeminde dönebilme hakkı olsa da bu tür vekâlete limit koyma hakkı yoktur. Konu, örfî istisnayla ilişkilendirildiğinde ise aksine bir hüküm ortaya çıkar. Koca, vekiline: "Eşimi boşa eğer dilersen" derse vekil, o kadını sadece belirlenen mecliste boşayabilmekte, kocanın ise verdiği vekâletten dönme hakkı bulunmamaktadır. Çünkü kocanın örfî istisnayı lafzen cümlede kullanması tevkil değil, temlik anlamı taşımaktadır. Vekilin, başkası adına yaptığı tasarruf her ne kadar kendi dilemesine bağlı olsa da aslında vekili olduğu kişinin dilemesiyle işlerlik kazanır. Temlikte ise baştan itibaren başkasının dilemesi olmaksızın mâlik kişi istediği tasarruf hürriyetine sahiptir. ${ }^{162}$

\section{Sonuç}

Diğer fikhî konularda olduğu gibi fikıh usûlü ilminin fürû-i fıkıh ilmi ile sıkı sıkıya bağlı olduğu bu araştırmanın konusu olan örfî istisnayla bir kez daha gözler önüne serilmiştir. Araştırma neticesinde aslında daha çok iman ve itikat açılarından bir kelam konusu olan örfî istisna, fıkıh ilminde insanlar tarafından bazı alanlarda sıkça başvurulan bir çıkış kapısı olarak nitelendirilebilir. Bu çıkış kapısı da yaşantısını din üzere sürdürmek isteyen müslümanlara bazı noktalarda dara düşmeden rahat hareket edebilmelerine olanak sağlayabilmek için Şâri' tarafından konulmuştur. Aksi bir durum olsaydı hatalarla müsemma olan insanın dini yönden yaşam alanı daralacak, pek çok sıkıntıya duçar olacaktı. İşte örfî istisnanın dindar bir insan için ne kadar hayati öneme sahip olduğu bu araştırma neticesinde ortaya çıkmıştır. Zaten alışverișten hibeye, nikâhtan talâka, ikrardan yemin ve nezir ahkâmına varıncaya kadar yaşamın birçok alanında örfî istisnanın tatbik edilmesi, onun insan için ne kadar önemli olduğunu kanıtlar mahiyettedir. Ancak herhangi bir kelamda zikredilen her örfî istisnanın da geçerli olmadığını, geçerli olabilmesi için bazı farklı görüş ve deliller dikkate alınmazsa genel olarak kasıt, niyet, kararlı ve doğru bir telaffuz, kelama muttasıl olma, kefâret ve atıf edatı olan "vav" (و) ile aynı cümlede bulunmama, "şâae" (شاء) ve ondan müştak fiil ve isimlerle kullanılma ve sadece Allah'a veya Allah'ın dışındaki varlıklara izâfeti gibi şartları haiz olması gerektiğini burada belirtmek yerinde olacaktır.

Örfî istisnanın hükmüne gelince, fakihler tarafından herhangi bir kelama örfî istisnanın ta'lik edilmesi evlâ, sünnet veya vâcip; ta'lik edilmemesi ise mekruh veya haram olduğuna hükmedildiği, sonuçta ulemâ arasında bir ittifak sağlanamadığı görülmüştür. Yine aynı ihtilaf örfî istisnanın zikredilmediğinde telâfisinin hemen, aynı mecliste, daha sonra, dört ay, bir yıl veya iki yll olarak tayin edilmesi hususunda da söylenebilir.

\footnotetext{
161 Karâfî, el-Furûk, 1/77, 79. Konuyla ilgili daha geniş bilgi için bk. İbnü'l-Hümâm, Fethü'l-kadîr, 4/ 100.

162 Kâsânî, Bedâiu's-sanâi', 3/122; İbnü'l-Hümâm, Fethü'l-kadîr, 4/99-100. Bu tür konularda vekâletin çeșitleri ve yetki sınırı hakkında geniş bilgi için bk. Kâsânî, Bedâiu's-sanâi', 3/122-23.
} 
Örfî istisna bazı kaynaklarda manevi istisna olarak isimlendirilse de özellikle son dönemde kaleme alınan eserlerde örfî istisna ismiyle anılır olduğu müşahede edilmiştir. Örfî istisnanın yerine fıkıh terminolojisinde ayrıntıda küçük nüanslar bulunmakla beraber "mâşallah", "bi-iznillah", "meșietullah" ve "iradetullah" gibi kelimeler de istimal edildiği görülmüștür.

Cumhura göre ayrıntıda farklılık bulunsa da İslam hukukunda bazı ibadet esaslarında örfî istisnanın zikredilmesi teşvik edildiği gibi zikredilmediğinde herhangi bir günahının olmayacağı; ancak duada kullanılmasının gerekli olduğu anlașılmıștır. Keza nikâh, talâk, ikrar ve yemin ahkâmında da cümle içerisinde örfî istisna bulunursa gerekli șartları taşıması durumunda istisna amel etmekte, anılan akitler ise bâtıl hale gelmektedir. Hanbelî mezhebinin ise genelde farklı gerekçelerle bazı konularda cumhurla aynı çizgide hareket ettiği dikkatlerden kaçmamıştır. Konu, alış-veriş ahkâmına gelince örfî istisnanın kullanılmaması her ne kadar bazı âlimlerce tercih edilse de genel görüșe göre kullanılmasında fayda görüldüğü mülahaza edilmiştir.

Hanefî mezhebi genel olarak diğer akit ve tasarruflarda olduğu gibi örfî istisnada da mecliste aynı konunun konuşulması ve konunun değişmemesi şartıyla örfî istisnanın birtakım hükümleri doğurabileceğini ileri sürmüşken; Hanbelîler ise aynı mecliste bulunmanın şart olmadığını ve niyetin bu konuda esas belirleyici bir rol oynadığını kabul etmişlerdir.

\section{Kaynakça}

Abdü'l-Mün'im, Mahmûd Abdurrahmân. Mu'cemü'l-mustalahât. 3 cilt. b.y.: Dâru'l-fazîle, ts.

Âmidî, Ebü'l-Hasan Seyfeddin Ali b. Muhammed. el-ihkâm fî usûli'l-ahkâm. thk. Abdürrezzâk Afîfî. 4 cilt. Beyrut: el-Mektebü'l-islâmî, ts.

Askerî, Ebû Hilal Hasan b. Abdullah b. Sehl. Mu'cemü'l-furûk. thk. Şeyh Beytullah Bayat. b.y.: Müessesetü'n-Neşri'l-İslâmî, 1412/1991.

Berhâmî, Yâsir b. Hüseyn. el-Furkān beyne ulemâi'r-Rahmân. thk. Abdurrahmân b. Abdilkerîm. b.y: Dâru'l-Minhâc, 1428/2007.

Buhârî, Ebû Abdillah Muhammed b. İsmail. el-Câmiu's-Sahîh. 9 cilt. b.y.: y.y., 1422.

Buhûtî, Mansûr b. Yûnus b. Salâhuddîn. Keşşâfü'l-kıınâ'. 6 cilt. Beyrut: Dâru'l-Kütüb, ts.

Cessâs, Ahmed b. Ali Ebû Bekr er-Râzî. el-Fusûl fi'l-usûl. 4 cilt. Kuveyt: Vizâratü'l-evkāf, $1414 / 1994$.

Cüveynî, İmâmü'l-Haremeyn Ebü'l-Meâlî Rüknüddin b. Yusuf. et-Telhîs fî usûli'l-fikh. thk. Abdullah Nebâlî. 3 cilt. Beyrut: Dâru'l-Beşâir, ts.

Dilthey, Wilhelm. Hermeneutik ve Tin Bilimleri. çev. Doğan Özlem. İstanbul: Notos Kitap, 2012. Durmuș, İsmail. "İstînâf". Türkiye Diyanet Vakfı İslam Ansiklopedisi. 23/ 367-368. Ankara: TDV Yayınlarl, 2001.

Düsûkī, Şemseddin Muhammed. Hâşsiyetü'd-Düsûkī alâşs-şerhi'l-kebîr. b.y: Dâru'l-Fikr, ts.

Ebû Ceyb, Sa'dî. el-Kāmûsu'l-fikhî. Suriye: Dâru'l-Fikr, 1413/1993.

Ebû Dâvûd, Süleyman b. el-Eş'as es-Sicistanî el-Ezdî. Sünen-i Ebî Dâvûd. thk. Muhammed Muhyiddin Abdülhamid. 4 cilt. Beyrut: y.y., ts.

Ebû Hubeyb, Sa'dî. el-Kāmûsu'l-fikhî. Dımaşk: Dâru'l-Fikr, 1408/1988.

Gazzâlî, Ebû Hâmid Muhammed b. Muhammed. el-Mustasfâ. thk. Muhammed Abdüsselâm. Beyrut: Dâru'l-Kütüb, 1413/1993.

Hafâcî, Şihâbüddin Ahmed b. Muhammed. Hâşiyetü'ş-şihâb alâ tefsîri'l-Beydâvî. 8 cilt. Beyrut: Daru Sâdır, ts. 
İbn Âbidîn, Muhammed Alâuddîn. Reddü'l-Muhtâr ale'd-Dürri'l-Muhtâr. 6 cilt. Beyrut: Dâru'lFikr, 1412/1992.

İbn Âşur, Muhammed Tâhir. Tahrîrul'-ma'nâ's-sedîd. 30 cilt. Tunus: Dâru't-Tunusî, 1404/1984. İbn Bâz, Abdülaziz b. Abdullah. Mecmûu Fetâvâ. 30 cilt. b.y.: y.y., ts.

İbn Cevzî, Ebü'l-Ferec Abdurrahman b. Ali. Nüzhetü'l-a'yüni'n-nezâir. thk. Muhammed Abdülkerim. Beyrut: Müessesetü'r-Risâle, 1404/1984.

İbn Hazm, Ali b. Ahmed b. Said. el-ihkâm fì usûli'l-ahkâm. thk. Ahmed Şakir. 8 cilt. Beyrut: Dâru'l-Âfâk, ts.

İbn Kayyim el-Cevziyye, Ebû Abdillah Muhammed b. Ebû Bekr. I'lâmü'l-muvakklîn. 7 cilt. Suudi Arabistan: Dâru İbni'l-Cevziyye, 1423/2002.

İbn Kudâme, Muvaffakuddîn Abdullah b. Ahmed. el-Muğnî. 10 cilt. b.y.: Mektebetü Kahire, $1387 / 1968$.

İbn Kudâme, Muvaffakuddîn Abdullah b. Ahmed. Ravzatü'n-nâzır ve cünnetü'l-münâzır. 2 cilt. b.y.: Müessesetü'r-Reyyân, 1423/2002.

İbn Mâce, Ebû Abdillah Muhammed b. Yezid. Sünen-i İbni Mâce, thk. M. Fuad Abdülbaki. 2 cilt. b.y.: Dâru İhyâi'l-Kütübi'l-Arabî, ts.

İbn Mâze, Ebü'l-Meâlî Burhânüddin Abdülazîz. el-Muhîtü'l-burhânî. thk. Abdülkerim Sâmî. 9 cilt. Beyrut: Dâru'l-Kütüb, 1424/2004.

İbnü'l-Hümâm, Kemâlüddin Muhammed. Fethü'l-kadîr. 10 cilt. b.y.: Dâru'l-Fikr, ts.

İsfehânî, Ebü'l-Kāsım Hüseyin b. Muhammed. el-Müfredâtfî Garîbi'l-Kur'ân. thk. Safvân Dâvudî. Beyrut: Dâru'l-kalem, 1412/1991.

İsnevî, Abdürrahim b. Ali. el-Kevkebü'd-dürriyye. thk. Hasan Avvâd. Amman: Dâru Ammâr, $1405 / 1984$.

Karâfî, Ebu'l-Abbas Ahmed b. İdrîs b. Abdurrahmân. el-Furûk. 4 cilt. b.y.: Âlemü'l-Kütüb, ts.

Karâfî, Ebu'l-Abbas Ahmed b. İdrîs b. Abdurrahmân. ez-Zehîre fi'l-fikh. thk. Muhammed Hacî. 14 cilt. Beyrut: Daru'l-Garb, 1414/1994.

Kâsânî, Alâüddin el-. Bedâiu's-sanâi'. 7 Cilt. Beyrut: Dâru'l-Kütübi'l-İlmiyye, 1406/1986.

Kefevî, Ebü'l-Bekā Eyyüb b. Musa. Külliyyât. thk. Adnan Derviş. Beyrut: Müessesetü'r-Risâle, ts.

Kur'ân-ı Kerîm Meâli. çev. Halil Altuntaş - Muzaffer Şahin. Ankara: Diyanet İşleri Başkanlığı Yayınları, 3. Basım, 2009.

Kurtubî, Ebû Abdillah Muhammed b. Ahmed. el-Câmi' li Ahkâmi'l-Kur'an. thk. Ahmed Berdûnî. 20 cilt. Kahire: Dâru'l-Kütübi'l-Mısriyye, 1383/1964.

Mâverdi, Ebü'l-Hasan Ali b. Muhammed Habib. el-Hâvi'l-kebîr. thk. Ali Ma'vez. 19 cilt. Beyrut: Dâru'l-Kütüb, 1419/1999.

Münazzametü'l-arabiyye. "Vsl". Mu'cemü'l-arabiyyi'l-esâsî. b.y.: Durûs, 1419/1999.

Müslim, Ebü’l-Hüseyn Müslim b. el-Haccâc. el-Câmi'u'ș-șahîhh. thk. Muhammed Fuâd Abdülbâkī. 5 cilt. Beyrut: Dâru İhyâi't-Türâsi'l-Arabî, ts.

Nesâî, Ebû Abdirrahman Ahmed b. Şuayb b. Ali. es-Sünenü'l-kübrâ. thk. Hasan Çelebi. 10 cilt. Beyrut: Müessesetü'r-Risâle, 1421/2001.

Nesâî, Ebû Abdirrahman Ahmed b. Şuayb b. Ali. Sünen. thk. Abdülfettah Ebû Gudde. 8 cilt. Halep: Mektebü'l-Matbûâti'l-İ̀slâmiyye, 1406/1986.

Nevevî, Ebû Zekeriyyâ Yahyâ b. Şeref b. Mürî. Ravzatü't-tâlibîn. thk. Züheyr Şâvîş. 12 cilt. Beyrut: Mektebetü'l-İslâmî, 1411/1991.

Pala, Ali İhsan. İslâm Hukuk Metodolojisinde Emir ve Yasakların Yorumu. Ankara: Fecr Yayınları, 2009.

Râzî, Ebû Abdillah Fahrüddîn Muhammed b. Ömer. et-Tefsîru'l-kebîr. 32 cilt. Beyrut: Dâru İhyâi't-Turâs, 1420/1999. 
Râzî, Ebû Bekr b. Abdilkadir er-. Muhtâru's-sihâh. thk. Yusuf Şeyh Muhammed. Beyrut: Mektebetü'l-Asriyye, 1419/1999.

Remlî, Muhammed b. Ahmed b. Hamza Şihâbüddîn. Şerhu Sünen-i Ebî Dâvûd. thk. Hâlid Rıbâd. 20 cilt. Mısır: Dâru'l-Felâh, 1437/2016.

Sahnûn, Ebû Saîd Abdüsselâm. el-Müdevvene. 4 cilt. Beyrut: Dâru'l-Kütüb, 1414/1994.

Semerkandî, Ebû Bekr Alâuddin. Tuhfetü'l-fukahâ. 3 cilt. Beyrut: Dâru'l-Kütüb, 1414/1994.

Serahsî, Ebû Bekr Şemsü'l-eimme Muhammed. el-Mebsût. 30 cilt. Beyrut: Dâru'l-Mârife, $1414 / 1993$.

Serahsî, Ebû Bekr Şemsü'l-eimme Muhammed. Usûlü's-Serahsî. 2 cilt. Beyrut: Dâru'l-Marife, ts.

Suyûtî, Celâlüdddîn. el-Eşbâh ve'n-nezâir. Beyrut: Dâru'l-Kütüb, 1410/1990.

Şa'bân, Zekiyyüddîn. İslâm Hukuk İlminin Esasları. çev. İbrahim Kâfi Dönmez. Ankara: Türkiye Diyanet Vakfı Yayınları, 1999.

Şirbînî, Şemsüddîn Muhammed b. Ahmed el-Hatîb. Muğni'l-muhtâc. 6 cilt. Beyrut: Dâru'lKütüb, 1414/1994.

Teftâzânî, Sa'duddin Mes'ûd b. Ömer. Şerhu't-Telvîh ale't-Tavzîh. 2 cilt. Mısır: Mektebetü Sabîh, ts.

Tirmizî, Ebû İsa Muhammed b. İsa. Sünenü't-Tirmizî. thk. Ahmed Muhammed Şâkir. 5 cilt. Mısır: $1395 / 1975$.

Vizâratü'l-evkāf ve'ş-şüûni'l-islâmiyye. "İkrâr". Mevsûatü'l-fikhiyye. Kuveyt: Dâru's-Selâsil, $1427 / 2006$.

Vizâratü'l-evkāf ve'ş-şüuni'l-islâmiyye. "İstisna". Mevsûatü'l-fikhiyye. Kuveyt: Dâru's-Selâsil, $1427 / 2006$.

Vizâratü'l-evkāf ve'ş-şüûni'l-islâmiyye. "Meşîet". Mevsûatü'l-fikhiyye. Kuveyt: Dâru's-Selâsil, $1427 / 2006$.

Vizâratü'l-evkāf ve'ş-şüûni'l-islâmiyye. "Nikâh". Mevsûatü'l-fikhiyye. Kuveyt: Dâru's-Selâsil, $1427 / 2006$.

Vizâratü'l-evkāf ve'ş-şüûni'l-islâmiyye. "Vudû". Mevsûatü'l-fikhiyye. Kuveyt: Dâru's-Selâsil, $1427 / 2006$.

Zebîdî, Muhammed b. Muhammed Ebü'l-Feyz. "Sny", Tâcu'l-arûs. thk. Mecmûa mine'lmuhakkıkîn. 37: 295. b.y.: Dâru'l-Hidâye, ts.

Zerkeşî, Ebû Abdillah Bedruddin b. Bahadır. el-Bahru'l-muhît. 8 cilt. Beyrut: Dâru'l-Kütüb, $1414 / 1994$. 